\title{
Groundwater nitrate concentration evolution under climate change and agricultural adaptation scenarios: Prince Edward Island, Canada
}

\author{
Daniel Paradis ${ }^{1}$, Harold Vigneault ${ }^{2}$, René Lefebvre ${ }^{2}$, Martine M. Savard ${ }^{1}$, Jean-Marc Ballard ${ }^{2}$, and \\ Budong Qian ${ }^{3}$ \\ ${ }^{1}$ Natural Resources Canada, Geological Survey of Canada, Quebec City, Canada \\ ${ }^{2}$ Institut national de la recherche scientifique, Centre Eau Terre Environnement (INRS-ETE), \\ Quebec City, Canada \\ ${ }^{3}$ Agriculture and Agri-Food Canada, Eastern Cereal and Oilseed Research Centre, Ottawa, Canada
}

Correspondence to: Daniel Paradis (daniel.paradis@canada.ca)

Received: 17 June 2015 - Published in Earth Syst. Dynam. Discuss.: 11 August 2015

Revised: 22 January 2016 - Accepted: 15 February 2016 - Published: 9 March 2016

\begin{abstract}
Nitrate $\left(\mathrm{N}^{-\mathrm{NO}_{3}}\right)$ concentration in groundwater, the sole source of potable water in Prince Edward Island (PEI, Canada), currently exceeds the $10 \mathrm{mg} \mathrm{L}^{-1}\left(\mathrm{~N}_{-N_{3}}\right)$ health threshold for drinking water in $6 \%$ of domestic wells. Increasing climatic and socio-economic pressures on PEI agriculture may further deteriorate groundwater quality. This study assesses how groundwater nitrate concentration could evolve due to the forecasted climate change and its related potential changes in agricultural practices. For this purpose, a tridimensional numerical groundwater flow and mass transport model was developed for the aquifer system of the entire Island $\left(5660 \mathrm{~km}^{2}\right)$. A number of different groundwater flow and mass transport simulations were made to evaluate the potential impact of the projected climate change and agricultural adaptation. According to the simulations for year 2050, N-NO 3 concentration would increase due to two main causes: (1) the progressive attainment of steady-state conditions related to present-day nitrogen loadings, and (2) the increase in nitrogen loadings due to changes in agricultural practices provoked by future climatic conditions. The combined effects of equilibration with loadings, climate and agricultural adaptation would lead to a 25 to $32 \%$ increase in $\mathrm{N}^{-\mathrm{NO}_{3}}$ concentration over the Island aquifer system. The change in groundwater recharge regime induced by climate change (with current agricultural practices) would only contribute 0 to $6 \%$ of that increase for the various climate scenarios. Moreover, simulated trends in groundwater $\mathrm{N}-\mathrm{NO}_{3}$ concentration suggest that an increased number of domestic wells (more than doubling) would exceed the nitrate drinking water criteria. This study underlines the need to develop and apply better agricultural management practices to ensure sustainability of long-term groundwater resources. The simulations also show that observable benefits from positive changes in agricultural practices would be delayed in time due to the slow dynamics of nitrate transport within the aquifer system.
\end{abstract}

\section{Introduction}

Significant increases in groundwater nitrate concentration $\left(\left[\mathrm{NO}_{3}\right]\right)$ are caused largely by sewage leaks, wastewater treatment without denitrification, improper management of wastewater effluents and overuse of fertilizers and/or animal waste. These nitrate sources are responsible for the contamination of numerous aquifers, especially in those areas where groundwater is replenished directly from the surface over large areas. Nitrate contamination is often associated with anthropogenic activities at ground surface, such as the fertilization of agricultural crops. Once groundwater is contaminated, remediation is difficult, thus the prevention of contamination is the primary strategy used for water quality management (Ghiglieri et al., 2009). 
Groundwater is the sole source of potable water in the Province of Prince Edward Island (PEI) in eastern Canada, and it plays a dominant role in surface water quality as well. Besides being a concern for drinking water quality, excessive nitrate levels contribute to eutrophication of surface waters, especially in estuarine environments (Somers and Mutch, 1999). Only one watershed among the 50 watersheds delineated in PEI still has groundwater with a mean $\left[\mathrm{NO}_{3}\right]$ within natural background levels $\left(<1 \mathrm{mg} \mathrm{L}^{-1} \mathrm{~N}-\mathrm{NO}_{3}\right)$. Furthermore $6 \%$ of supply wells exceed the recommended maximum concentration limit of $10 \mathrm{mg} \mathrm{L}^{-1}\left(\mathrm{~N}-\mathrm{NO}_{3}\right)$ for drinking water (Health Canada, 2004; Somers, 1998; Somers et al., 1999). Over the past decade, several studies have documented the nitrate problem in PEI groundwater (Somers, 1998; Somers et al., 1999; Young et al., 2002; Savard et al., 2007) and suggested that elevated nitrate levels are often associated with agricultural activities, especially the use of fertilizers for row crop production. In addition, water quality surveys have recorded important increases (more than doubling since 1980) of $\left[\mathrm{NO}_{3}\right]$ in groundwater and surface water in some areas of the province (Somers et al., 1999).

According to simulations made with the global circulation model (GCM) for Canada, temperature increases in the order of 2 to $4{ }^{\circ} \mathrm{C}$ by 2050 is expected at the country scale (Hengeveld, 2000). Projected changes in annual precipitation over Canada remain within $10 \%$ of present levels until 2050, with most of the increases occurring during winter months. Since global warming is expected to change the hydrologic cycle (Gleick, 1986) as well as the agricultural practices (Olesen and Bindi, 2002; McGinn and Shepherd, $2003)$, it could, in turn, impact groundwater $\left[\mathrm{NO}_{3}\right]$. The overall impact on groundwater $\left[\mathrm{NO}_{3}\right]$ will likely depend on both the magnitude of the change induced by climate change on the hydrologic cycle and how agriculture will adapt to these changes. The combined pressures of climatic change on groundwater recharge and agricultural practices, together with the need to preserve groundwater quality for the residents of PEI, illustrate the importance of effective long-term strategies for water management. The aim of this study is then to assess the potential impact of both climate change and modified agricultural practices on future groundwater $\left[\mathrm{NO}_{3}\right]$ for the entire PEI $\left(\sim 5660 \mathrm{~km}^{2}\right)$.

Nitrate concentration in groundwater depends on the mass loadings and the amount of water infiltrating the soils down to the water table. In other words, future $\mathrm{N}-\mathrm{NO}_{3}$ concentration can be estimated as the mass of nitrate leached over the volume of recharge per unit area carrying out this mass to the aquifer (groundwater recharge) under projected climatic conditions. Climate change impacts were simulated using different GCMs and $\mathrm{CO}_{2}$ emission scenarios for the period of 2040-2069, to assess the sensitivity of the climatic variables. The stochastic weather generator AAFC-WG (Hayhoe, 2000) was then used to adjust daily temperature and precipitation of selected large-scale GCM scenarios to the scale of the Island and allow simulations of groundwater recharge over the Island using the hydrologic infiltration model HELP (Schroeder et al., 1994). The physical parameters used by this infiltration model allow an assessment of the impact of changing climatic parameters on the hydrological cycle, which includes groundwater recharge. Moreover, the amount of nitrogen leaching to the aquifer was estimated on the basis of the residual soil nitrogen (RSN) indicator (Yang et al., 2007) under present-day conditions as well as considering agricultural adaptation scenarios in response to the increase of crop heat units, effective growing degree-days and agroeconomic trends (De Jong et al., 2008).

Studying the impacts of climate change and agricultural management scenarios on groundwater quality also necessitates understanding the aquifer system dynamics. Particularly, flow and transport simulations are needed to assess the nitrate residence time and the aquifer response to changes in practices or climatic conditions. While there have been many studies relating the effect of climate changes on groundwater resources (e.g., Yussof et al., 2002; Allen et al., 2004, 2010; Scibek and Allen, 2006; Green et al., 2007a, b; Hsu et al., 2007; Jyrkama and Sykes, 2007; Serrat-Capdevila et al., 2007; Woldeamlak et al., 2007; Holman et al., 2009; Crosbie et al., 2010; McCallum et al., 2010; Okkonen et al., 2010; Rozell and Wong, 2010; Zhou et al., 2010; Beigi and Tsai, 2015), there are few published studies which attempt to relate climate change to changes in groundwater $\left[\mathrm{NO}_{3}\right]$ (e.g., De Jong et al., 2008; Ducharne et al., 2007; Holman et al., 2005a, b; Jackson et al., 2007). In their works, De Jong et al. (2008) and Jackson et al. (2007) estimated mass of nitrogen $(\mathrm{N})$ leaching through the unsaturated zone for different scenarios to relate with $\left[\mathrm{NO}_{3}\right]$ measured in wells - that is, assuming a direct relationship between nitrate leachate and groundwater $\left[\mathrm{NO}_{3}\right]$ regardless of the aquifer system dynamics. While the semi-empirical hydrological model proposed by Holman et al. $(2005 \mathrm{a}, \mathrm{b})$ to predict $\left[\mathrm{NO}_{3}\right]$ in both surface water and groundwater includes a groundwater store, such model does not simulate spatial and temporal groundwater flow patterns that control nitrate transport in the aquifer system. For instance, Ducharne et al. (2007) demonstrated that modeling of the aquifer system using a physically based groundwater flow model allowed to simulate the inertia of the aquifer system, which has a considerable impact on $\left[\mathrm{NO}_{3}\right]$ measured in wells. In this study, the evolution of groundwater $\left[\mathrm{NO}_{3}\right]$ under a changing climate was modeled using the physically based groundwater flow and solute transport numerical simulator FEFLOW (Finite Element subsurface FLOW system; Diersch, 2010) considering the effect of the dual porosity of the fractured porous medium (sandstone), identified by Jackson et al. (1990) as being responsible for the persistence of pesticides in the aquifer system of PEI. In particular, the hydrogeological model developed for the entire province was based on knowledge gained from the Wilmot watershed (Jiang and Somers, 2009; Paradis et al., 2006, 2007), which is representative of most other regions of PEI regarding land use, soils, physiography, geology and hy- 


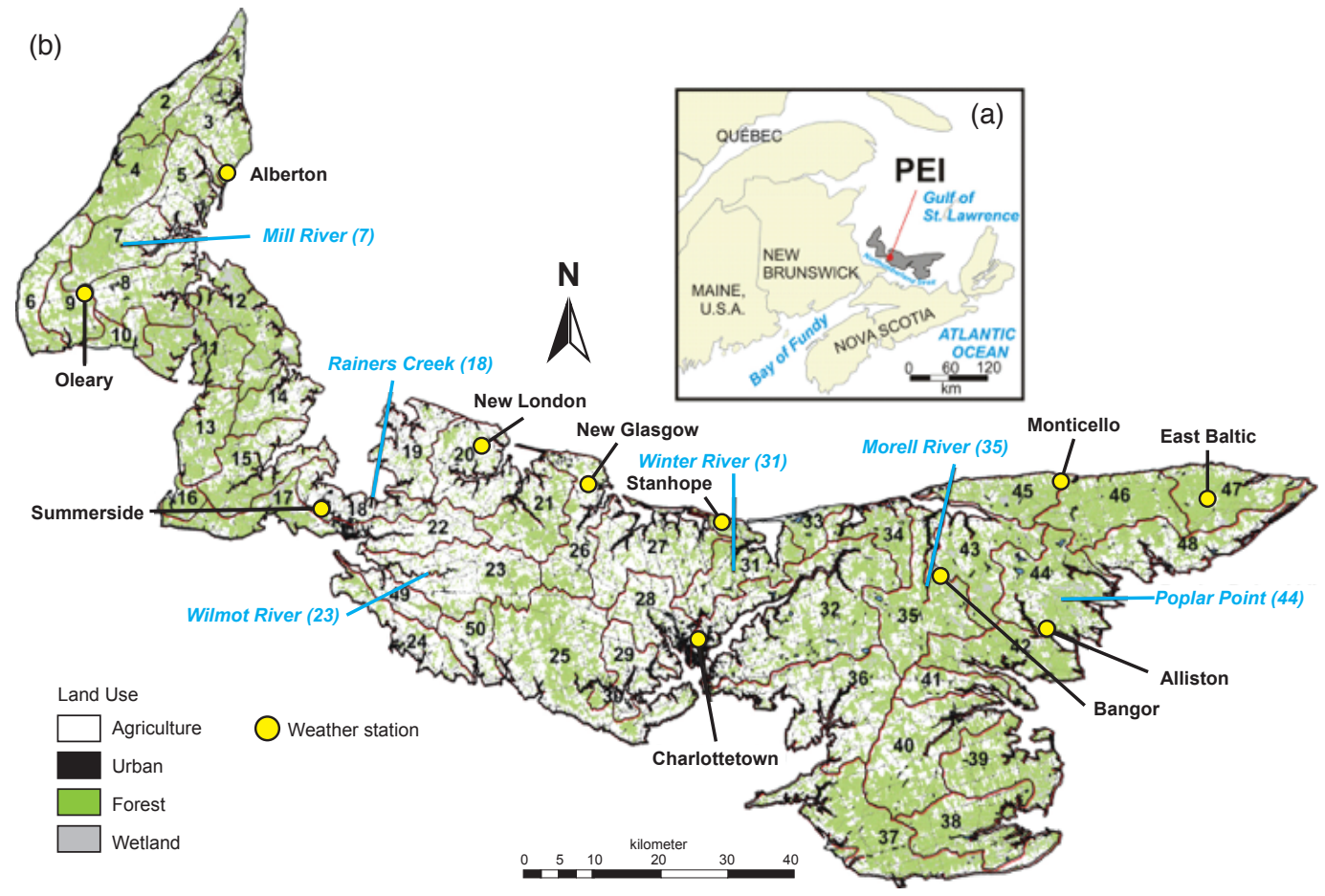

Figure 1. (a) Location of Prince Edward Island (PEI) in eastern Canada. (b) Limits of the watersheds (numbered area delineated with brown lines, see names Table S1), with identification of the major rivers (names in blue), along with land use (see legend) and location of the weather stations (names in black).

drogeology. The hydrogeological model was calibrated with historical hydrogeological records of conditions specific to the Island: hydraulic heads, groundwater discharge to river and $\left[\mathrm{NO}_{3}\right]$ measured in both wells and rivers.

The novelty of this study is to provide a quantitative comparison of climate change effects and agricultural adaptation impacts on the future evolution of $\left[\mathrm{NO}_{3}\right]$, taking into account potential changes in groundwater recharge and nitrate leached. Also, the general framework developed for the integration of the knowledge related to the aquifer system, climatic parameters and agricultural practices into a comprehensive calibration approach with site-specific records to narrow uncertainty in model parameters, could be applied elsewhere to guide groundwater resource and quality management.

\section{Prince Edward Island study area}

PEI, located in eastern Canada, covers approximately $5660 \mathrm{~km}^{2}$ and is $225 \mathrm{~km}$ long by 3 to $65 \mathrm{~km}$ wide (Fig. 1 and Table 1). Topographic elevation ranges from sea level to $140 \mathrm{~m}$ a.s.l. (above sea level). PEI is predominantly rural, with $39 \%$ of its surface covered by agricultural lands and $45 \%$ by forests. Forests mostly cover the eastern and western portions of the Island, whereas agricultural activities are
Table 1. Main physiographic and land use characteristics of Prince Edward Island (land use based on a LANDSAT image for 2000).

\begin{tabular}{ll}
\hline \multicolumn{2}{c}{ Physiography } \\
\hline Area & $5660 \mathrm{~km}^{2}$ \\
Width & $3-65 \mathrm{~km}$ \\
Length & $225 \mathrm{~km}$ \\
Elevation (a.s.l.) & $0-140 \mathrm{~m}$ \\
\hline \multicolumn{2}{c}{ Land use (\%) } \\
\hline Forest & 45 \\
Agriculture & 39 \\
Wetland & 7 \\
Residential, urban, industrial & 5.9 \\
Recreational & 0.3 \\
Miscellaneous & 2.8 \\
\hline
\end{tabular}

mostly concentrated in the central part. Residential, urban and industrial activities occupy less than $6 \%$ of the territory.

\subsection{Climate and hydrology}

The climate in the Island is humid continental, with long, fairly cold, winters and warm summers. Data selected from four weather stations geographically distributed across the Island (Fig. 1) show relatively similar conditions (Table 2). 
Table 2. Weather for Prince Edward Island (meteorological data for the 1971-2000 period). See Fig. 1 for locations of the weather stations.

\begin{tabular}{lrrrr}
\hline Weather characteristic & \multicolumn{3}{c}{ Station } \\
\cline { 2 - 5 } & O'Leary & Summerside & Charlottetown & Monticello \\
\hline Mean annual total precipitation $(\mathrm{mm})$ & 1141 & 1078 & 1173 & 1164 \\
Mean annual rain (mm) & 860 & 806 & 880 & 903 \\
Mean annual snow (mm) & 281 & 282 & 311 & 261 \\
Mean annual temperature $\left({ }^{\circ} \mathrm{C}\right)$ & 5.2 & 5.6 & 5.3 & 5.5 \\
Minimum mean monthly temperature $\left({ }^{\circ} \mathrm{C}\right)$ (January) & -8.6 & -7.9 & -8.0 & -7.4 \\
Maximum mean monthly temperature $\left({ }^{\circ} \mathrm{C}\right)$ (July) & 18.5 & 19.1 & 18.5 & 18.4 \\
\hline
\end{tabular}

As an example of the climatic conditions found on the Island, the mean annual precipitation at the Charlottetown weather station is $1173 \mathrm{~mm}$, most of which falls as rain $(75 \%)$. The mean annual temperature is about $5.3^{\circ} \mathrm{C}$ and means for monthly temperature range from $-8^{\circ} \mathrm{C}$ in January to $18.5^{\circ} \mathrm{C}$ in July. The Island can be divided into 50 watersheds comprising 241 sub-watersheds (Fig. 1). River basins are typically small, and the main rivers are estuarial over a significant portion of their length. Mean annual streamflow ranges from less than 0.66 to $2.88 \mathrm{~m}^{3} \mathrm{~s}^{-1}$ (Table 3 ).

\subsection{Geology and hydrogeological framework}

PEI is a crescent-shaped cuesta of continental red beds, Upper Pennsylvanian to Middle Permian in age, dipping to the northeast at about one to three degrees that consist of conglomerate, sandstone and siltstone in which sandstones are dominant (Van de Poll, 1983). The rock sequence underlying the Island is almost entirely covered by a layer of unconsolidated glacial material from a few centimeters to several meters in thickness (Prest, 1973). These deposits are generally derived from local sedimentary rock and include both unsorted tills and water-worked glacio-fluvial and glaciomarine deposits.

With few exceptions, the surficial sediments over PEI do not represent significant aquifers as they are not water saturated, so the sandstone constitutes the main aquifer. Because the geology of the Island is relatively homogeneous, the hydrogeological conceptual model for all PEI is assumed to be similar to the one defined for the Winter River and Wilmot River watersheds where Francis (1989) and Paradis et al. $(2006,2007)$ carried out extensive hydrogeological characterization. Based on these studies several observations relative to the hydrogeological framework of PEI can be made:

- The sandstone aquifer comprises a shallow high-flow system overlying a deep low-flow system (Fig. 2a). This is based on hydraulic conductivity profiles obtained from field multi-level packer tests in rock aquifer wells that show a rapid decrease of hydraulic conductivity with depth (Fig. 2b). This decrease is significant under a depth of 18 to $36 \mathrm{~m}$, according to location. The shal-
Table 3. Streamflow characteristics of selected rivers in Prince Edward Island (records are for 1972 to 2005, 1961 to 1995 and 1965 to 1991 for Wilmot, Morell, and Winter rivers, respectively). See Fig. 1 for locations of the rivers.

\begin{tabular}{lccc}
\hline \multirow{2}{*}{$\begin{array}{l}\text { Streamflow characteristics } \\
\left(\mathrm{m}^{3} \mathrm{~s}^{-1}\right)\end{array}$} & \multicolumn{3}{c}{ Watershed (drainage area in $\left.\mathrm{km}^{2}\right)$} \\
\cline { 2 - 4 } & $\begin{array}{c}\text { Morell } \\
(133)\end{array}$ & $\begin{array}{c}\text { Wilmot } \\
(45)\end{array}$ & $\begin{array}{c}\text { Winter } \\
(38)\end{array}$ \\
\hline Mean annual & 2.88 & 0.92 & 0.66 \\
Minimum monthly mean (September) & 1.10 & 0.44 & 0.24 \\
Maximum monthly mean (April) & 6.77 & 1.89 & 1.61 \\
\hline
\end{tabular}

low interval with higher permeability is defined as the high-flow system. Most domestic wells tap potable water in this high-flow system (Mutch, 1998; Rivard et al., 2008).

- The sandstone aquifer represents a double porosity system with fractures providing groundwater flow paths and the porous matrix providing storage capacity, both for water and solutes, including nitrate. The fractured sandstone is characterized by relatively high hydraulic conductivity, between $1 \times 10^{-6}$ and $3 \times 10^{-4} \mathrm{~m} \mathrm{~s}^{-1}$ (Fig. 2b), but it has a low storage capacity (1-3\%), as obtained from modeling of baseflow recession curves (Paradis et al., 2006, 2007) and seasonal nitrate sources in groundwater from isotopes (Ballard et al., 2009). In contrast, the matrix has a high porosity of about $17 \%$, but a much lower hydraulic conductivity as measured from laboratory core permeameter tests: mostly between $1 \times 10^{-8}$ and $5 \times 10^{-7} \mathrm{~m} \mathrm{~s}^{-1}$ but as low as $5 \times 10^{-10} \mathrm{~m} \mathrm{~s}^{-1}$ for mudstone (Francis, 1989).

- Comparison between field (Paradis et al., 2006, 2007; Francis, 1989) and laboratory (Francis, 1989) hydraulic conductivity measurements suggests that fractures play an important role in the rock aquifer permeability, and the general decrease in hydraulic conductivity with depth is the result of decreasing fracture aperture and frequency. Horizontal bedding of the sandstone forms the main fracture network above $35 \mathrm{~m}$ depth $(82 \%$ of all fractures; Francis, 1989). Over a large area, the rela- 

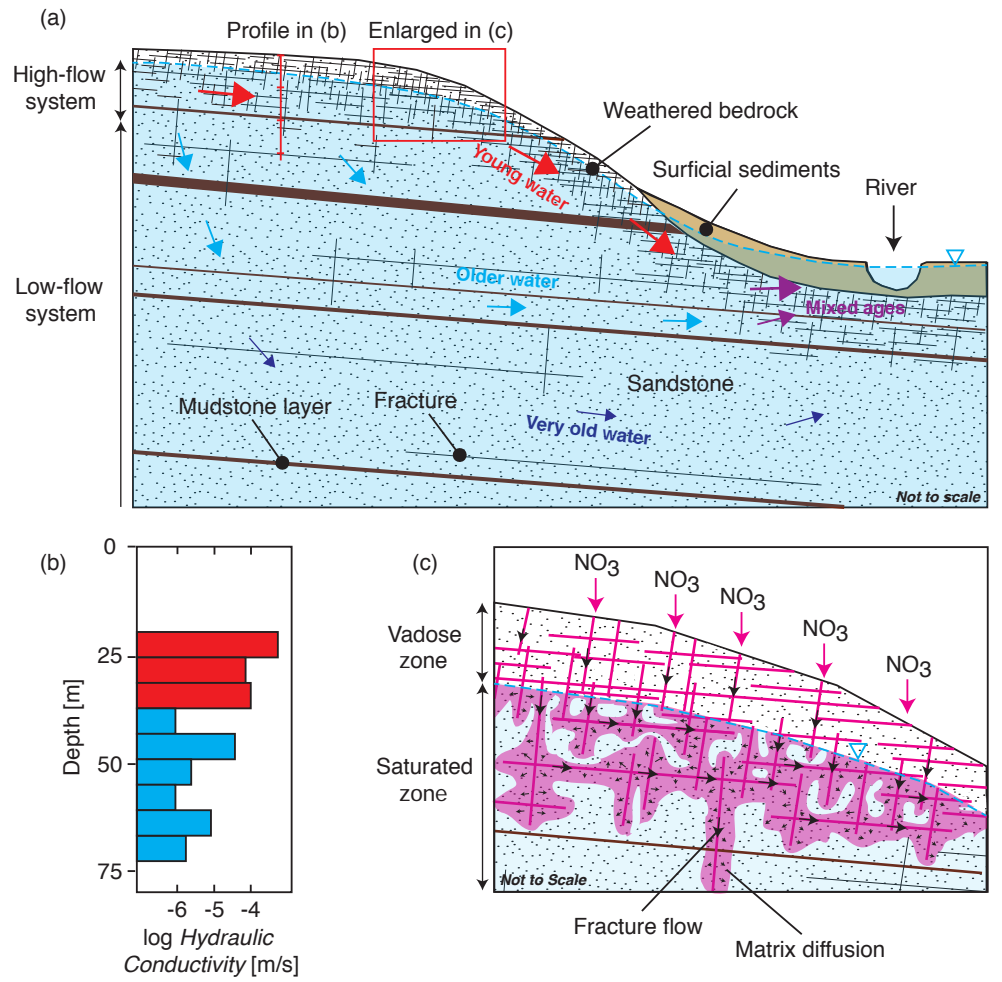

Figure 2. (a) Schematic conceptual model of the groundwater flow system along with (b) a typical profile of hydraulic conductivity showing distinct shallow high-flow (red) and deeper low-flow (blue) systems; and (c) a conceptualization of nitrate transport in the double-porosity sandstone aquifer with advective fracture flow and matrix diffusion.

tive homogeneity of the distribution and interconnection of fractures provides a typical "porous media" response to pumping, especially in the weathered high-flow rock aquifer system (Francis, 1989).

- Tritium analyses on groundwater samples in the highflow system indicate the presence of "modern groundwater" younger than 50 years. In the low-flow system, no tritium is observed but carbon-14 analyses provide groundwater ages between 5000 and 7000 years at depths ranging between 50 and $85 \mathrm{~m}$ below the water table (Paradis et al., 2006, 2007).

- Transient modeling of baseflow recession curves (the groundwater contribution to a river) for the Wilmot River watershed suggests that rivers gain water from the aquifer most of the year (Jiang and Somers, 2009) and there is a strong interaction between the high-flow system and the rivers (Paradis et al., 2007). This is also supported by seasonal sampling of nitrate carried out over a period of 2 years in domestic wells and in the Wilmot River that shows similar average $\left[\mathrm{NO}_{3}\right]$ as well as water and nitrate isotope properties (Savard et al., 2007, 2010).

In summary, it is inferred from the development of the conceptual hydrogeological model that groundwater flow and nitrate transport predominantly occur in the high-flow system (Fig. 2c). The shallow high-flow system essentially follows the ground topography and is hydraulically connected to rivers. Nitrate transported to the aquifer by infiltration of precipitation will first reach the shallow high-flow system and then eventually reach rivers mainly through fractures in weathered and fractured sandstone, which are significantly more permeable than the sandstone matrix itself. $\mathrm{Ni}$ trate transport rate through the aquifer system could however be reduced, as matrix diffusion occurs due to the contrast in $\left[\mathrm{NO}_{3}\right]$ between fractures and matrices. The high porosity of the sandstone matrix makes it an important repository for nitrate which could store or release nitrate, depending on geochemical conditions in the adjacent fracture network. Finally, it is also likely that a proportion of the nitrate transported in the high-flow system has reached the underlying low-flow system. Considering the reduced groundwater flow and the mostly old groundwater ages encountered in the lowflow system, the nitrate that may be present in the low-flow system may not have reached rivers yet. Note that in the case of the entire PEI, oxidizing aquifer conditions usually prevail in the sandstone aquifer and it was assumed that denitrification processes are negligible within the aquifer. Moreover, no natural geological sources of nitrate are expected to be present throughout the Island. The aquifer $\left[\mathrm{NO}_{3}\right]$ would then 
be controlled by water infiltration and nitrate leaching from the soil.

\section{Study methodology}

Figure 3 presents the general workflow followed to model the evolution of $\left[\mathrm{NO}_{3}\right]$ in groundwater of the PEI aquifer system, which is briefly described below with further details provided in the following sections:

- Climate change can itself be predicted on the basis of meteorological models with a large degree of uncertainty. Therefore, different climate change scenarios have to be considered in order to represent the potential range of impacts related to predicted temperature and precipitation. In this study, four climate scenarios were selected to provide future daily weather conditions for the period 2040-2069. These scenarios are based on different $\mathrm{GCMs}$ and $\mathrm{CO}_{2}$ emission scenarios for the period 2040-2069.

- The daily temperatures and precipitations of the four selected large-scale GCMs were downscaled using historical meteorological records of existing weather stations using the stochastic weather generator AAFC-WG (Hayhoe, 2000) in order to provide more realistic climate conditions of the Island.

- Groundwater recharge was obtained from the HELP infiltration model (Schroeder et al., 1994), which uses daily climate conditions and soil properties as input. As done by Croteau et al. (2010), recharge obtained from HELP was calibrated on the basis of present-day climate conditions, so that future recharge could be estimated using the four climate scenarios.

- Nitrate leaching to the aquifer system was estimated under present-day conditions and agricultural adaptation scenarios. This mass of nitrate leachate is determined on the basis of the residual soil nitrogen (RSN) indicator (Yang et al., 2007).

- Using present-day nitrate mass and groundwater recharge, a three-dimensional numerical model of groundwater flow and nitrate transport was developed and calibrated to represent the specific hydrogeological conditions of PEI using FEFLOW (Diersch, 2010). This model was then used to simulate the future evolution of $\left[\mathrm{NO}_{3}\right]$ under different climate change and agricultural adaptation scenarios that implied potential changes in groundwater recharge and nitrate leachate.

\subsection{Climate change scenarios and climate data downscaling}

The Intergovernmental Panel on Climate Change Special Report on Emission Scenarios (Nakicenovic and Swart,

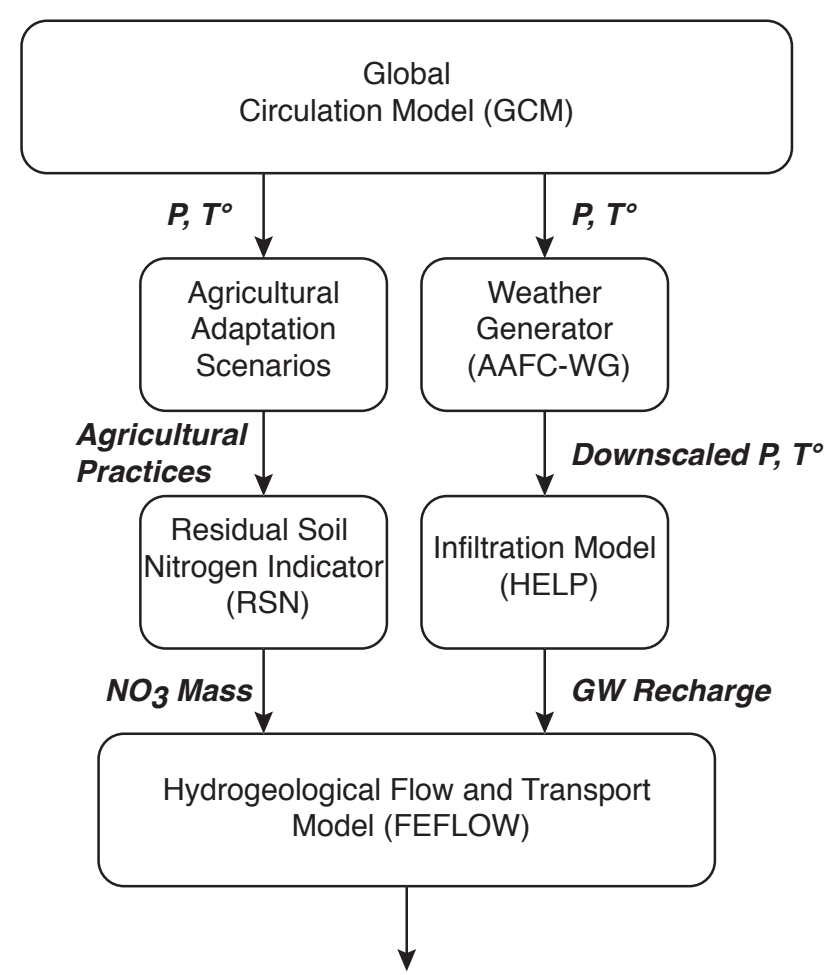

$\mathrm{NO}_{3}$ Concentrations in Groundwater

Figure 3. Workflow for the study of the potential impact of climate and agricultural practice changes on future groundwater nitrate concentration in the Prince Edward Island aquifer system.

2000) provides 40 different scenarios, which are all deemed "equally likely", but the A2 and B2 scenarios are widely adopted in climate change experiments and impact studies (IPCC, 2001). The A2 scenario envisions a population growth to 15 billion by year 2100 with rather slow economic growth and development. Consequently, the projected equivalent $\mathrm{CO}_{2}$ concentration rises from $476 \mathrm{ppm}$ in 1990 to $1320 \mathrm{ppm}$ in 2100 . The B2 scenario envisions slower population growth (10.4 billion by 2100$)$ with a more rapidly evolving economy, but with more emphasis on environmental protection. It therefore produces lower emissions $\left(\mathrm{CO}_{2}\right.$ concentration of $915 \mathrm{ppm}$ by 2100) and less warming than scenario A2. The A2 and B2 scenarios were simulated using two different GCMs, which are the CGCM2 (Flato and Boer, 2001) developed at the Canadian Centre for Climate Modelling and Analysis, and HadCM3 (Gordon et al., 2000) developed at the Hadley Centre for Climate Prediction and Research of the UK Meteorological Office. Daily outputs of maximum and minimum air temperature, and total precipitation were obtained electronically from the Canadian Centre for Climate Modelling and Analysis and the Hadley Centre through the Climate Impacts LINK project (Viner, 1996) for the four climate change scenarios labeled hereafter: CGCM2-A2, CGCM2-B2, HadCM3-A2 and HadCM3-B2. 
The AAFC-WG (Hayhoe, 2000) was used to generate synthetic continuous daily weather records for the historical period (1971-2000) and for two (2040-2069) climate scenarios using different GCMs (Fig. 3). The time period 20402069 is approximately corresponding to a doubling of atmospheric $\mathrm{CO}_{2}$ concentration (Qian et al., 2010). The AAFCWG is a stochastic weather generator that was developed for and evaluated in diverse Canadian climates (Qian et al., 2004). To obtain future climate data, daily outputs from the four climate change scenarios (CGCM2-A2, CGCM2-B2, HadCM3-A2 and HadCM3-B2) were downscaled with observed historical climate data from existing weather stations. A total of 11 weather stations were selected, covering PEI fairly evenly and having the best available historical weather data for 1971-2000 (Fig. 1). Observed historical weather data, including daily maximum and minimum air temperatures and daily precipitation, were provided by Environment Canada through their web site, and first used to calibrate an AAFC-WG model for each weather station. The parameters for the various statistical models used by the AAFC-WG were indeed estimated from historical observations independently for each station. Note that historical climate from synthetic weather data generated by AAFC-WG is generally not significantly different from observations (Qian and De Jong, 2007; Qian et al., 2011).

\subsection{Groundwater recharge}

Groundwater recharge simulations serving as input for the FEFLOW model was carried out with the physically based hydrologic model HELP (Schroeder et al., 1994) (Fig. 3). The model is quasi two-dimensional and the natural water balance components simulated include precipitation, interception of rainwater by leaves, evaporation by leaves, surface runoff, evaporation from soil, plant transpiration, snow accumulation and melting, and percolation of water through the soil profile. The advantage of using such a model is that temperature and precipitation resulting from climate scenarios may be directly used in the model to predict future groundwater recharge, once the model has been calibrated based on present-day data (e.g., Jyrkama et al., 2002; Allen et al., 2004; Croteau et al., 2010; Rivard et al., 2014).

The spatial estimation of groundwater recharge over PEI was obtained using $500 \times 500 \mathrm{~m}$ cells (total of 21168 ). For each cell, model parameters were retrieved and analyzed with geographical information software and a database management system. The HELP parameters used are summarized below.

- Soil profile: the soil profile is the vertical combination of natural soil and geological materials that compose the vadose and saturated zones. The surface soil information was assembled from various regional soil surveys conducted on the Island (Canadian Soil Information System, 2000). There were a total of 953 unique soil types identified on PEI that were regrouped into six distinct soil classes according to the dominant soil texture (A - sand or coarser; B - loamy sand or gravelly; $\mathrm{C}$ - sandy loam ( $<8 \%$ clay); D - fine sandy loam or very fine sandy loam; E - loam or silt loam; and F - sandy clay loam or clay loam). A typical soil profile consisting of three layers was used to their representation. The top layer is $0.5 \mathrm{~m}$ thick and consists of one of the six soil classes; layer 2 is $1-17 \mathrm{~m}$ thick and consists of unconsolidated glacial material; and bottom layer is $10 \mathrm{~m}$ thick and consists of weathered sandstone (highflow system).

- Initial moisture content: the initial water content of each soil profile layer was computed by the model as steady state values. HELP indeed assigned values for the initial water moisture storage of layers and simulates a 1-year period. These values were then used as initial values for the simulations. A sensitivity analysis of initial water content reveals that this parameter does not affect significantly groundwater recharge estimates as steady-state conditions can be assumed over the long simulation period.

- Surface runoff: surface runoff (also known as overland flow) is the flow of water that occurs when excess rainfall or snowmelt flows over the soil surface. Surface runoff was estimated using a modified Soil Conservation Service (SCS) curve-number method (USDA, 1986), as proposed by Monfet (1979). The modified method allows a more reliable estimation of surface runoff in watersheds with short concentration time and for precipitation patterns found in eastern Canada. The modified SCS method allows estimation of surface runoff to a river following a rainfall or snowmelt event using soil characteristics, land use, type of vegetation, soil humidity, and surface slope. Digital land use and land cover data were obtained from Landsat-7 images (CanImage, 2001).

- Solar radiation: the required daily values of precipitation, mean air temperature, and solar radiation were calculated. Precipitation and temperature were obtained from downscaled climate scenarios, while solar radiation data were generated using the weather generator provided by HELP. Solar radiation is computed according to precipitation (whether the day is wet or dry) and latitude.

- Evapotranspiration: the multi-layer procedure for calculating evaporation values from snow, soil, and leaves, as well as transpiration based on type of vegetation used the evaporative zone depth, maximum leaf-area index, growing season start and end day, average wind speed, and relative humidity. These parameters were evaluated from existing land cover, agricultural and climatic data. 
Table 4. Statistical analysis of model performance on calibration of different independent data sets for the simulation of groundwater flow and nitrate transport in the Prince Edward Island aquifer system.

\begin{tabular}{llrrr}
\hline Model & Calibration target & \multicolumn{3}{c}{ Model error } \\
\cline { 3 - 5 } & & $\begin{array}{r}\text { Correlation } \\
\text { coefficient } \\
(r)\end{array}$ & $\begin{array}{r}\text { Relative } \\
\text { error } \\
\text { (bias in \%) }\end{array}$ & $\begin{array}{r}\text { Root mean } \\
\text { square } \\
\text { error } \\
\text { (RMS in } \\
\%)\end{array}$ \\
& & & & 0.8 \\
\hline HELP & Groundwater recharge from baseflow & 0.64 & -66.8 & 19 \\
FEFLOW & Hydraulic head in open wells & 0.88 & 0.3 & 36 \\
FEFLOW & Baseflow recession in rivers & 0.96 & -0.3 & 30 \\
FEFLOW & Nitrate concentration in wells & 0.64 & & 3 \\
\hline
\end{tabular}

Groundwater recharge values simulated from HELP were calibrated against baseflow values estimated using the method of hydrograph separation with streamflow records (Furey and Gupta, 2001) to narrow uncertainty in the input parameters of HELP (e.g., Croteau et al., 2010). Baseflow is the groundwater contribution to river discharge (streamflow) and it is often used as an approximation of groundwater recharge when underflow (groundwater flow beneath and by-passing a river), evapotranspiration from riparian vegetation, and other losses of groundwater from the watershed are minimal (Risser et al., 2005). Hydrograph separation methods estimate the part of the streamflow hydrograph attributed to baseflow using semi-empirical filter techniques. The calibration was done with the historical records of temperature and precipitation (1971-2000) for three gauged streamflow stations with the most comprehensive time series (Morell, Wilmot and Winter, Fig. 1 for location). For each watershed, groundwater recharge with HELP was estimated by summing all individual 1-D soil profiles included in the watershed assuming that water reaching the aquifer for each soil profile contributes to the streamflow within the year. The most relevant parameters to calibrate were the evaporative zone depth and the heat insulation of the snow cover. The trend in groundwater recharge simulated with HELP is comparable to baseflow estimated with the Furey and Gupta (2001) method (Table 4), with a correlation coefficient of 0.64 and no significant bias (relative error close to 0 ) in the annual values. The error in the simulated values is $19 \%$ as expressed by the RMS error.

\subsection{Mass of nitrogen available for leaching and agricultural adaptation scenario}

The mass of nitrate available for transfer to groundwater was estimated with the residual soil nitrogen (RSN) indicator (Drury et al., 2007; Fig. 3). The RSN indicator estimates the quantity of inorganic soil $\mathrm{N}$ at the time of harvest, at the Soil Landscape of Canada (SLC) polygon level (Soil Landscapes of Canada Working Group, 2006). The RSN indicator is the difference between $\mathrm{N}$ inputs from chemical fertilizer $\mathrm{N}$, manure, biological $\mathrm{N}$ fixation by leguminous crops, and atmospheric deposition and outputs in the form of $\mathrm{N}$ in the harvested portion of the crops and pasture, and gaseous $\left(\mathrm{N}_{2}\right.$ and $\mathrm{N}_{2} \mathrm{O}$ ) losses to the atmosphere via denitrification. The total chemical fertilizer $\mathrm{N}$ is based on fertilizer recommendation applied to crops adjusted to the total manure $\mathrm{N}$ available for crops and improved pasture. The amount of available inorganic $\mathrm{N}$ from manure applied to crops and pasture take into consideration losses from storage and handling. It is estimated that $15 \%$ of manure $\mathrm{N}$ is lost during storage and handling (Burton and Beauchamp, 1986), $35 \%$ is added to the soil as organic N (Ontario Ministry of Agriculture and Food, 2003), and consequently $50 \%$ of $\mathrm{N}$ originally present in manure is inorganic $\mathrm{N}$ which would be available to crops during the year of application. Of this available $\mathrm{N}, 1.25 \%$ is lost as $\mathrm{N}_{2} \mathrm{O}$ emissions, and an equal portion is assumed to be lost through $\mathrm{N}_{2}$ production. Although soil mineralization and immobilization also occur on a seasonal basis, it is assumed that soils are in a steady-state situation, with no net change in soil organic $\mathrm{N}$ from one year to the next.

The main inputs of the RSN model consist of acreages for all major agricultural crops and their associated crop yields, as well as the type and number of livestock. These data are collected every 5 years through the census made by Agriculture and Agri-Food Canada and are allocated to SLC polygons based on the methodology described by Huffman et al. (2006). The RSN model was run for all 5 census years (1981, 1986, 1991, 1996 and 2001) and the output was averaged to obtain a "historical" RSN value for each of the 23 SLC polygons covering PEI (De Jong et al., 2008). The RSN values at the SLC polygon level could not be validated because independent data sets are not available at that scale. However, Yang et al. (2007) compared the total adjusted chemical fertilizer $\mathrm{N}$ recommendation (fertilizer recommendation minus available manure) with the total amount of $\mathrm{N}$ fertilizer sold in PEI. For the five censuses, the average ratio between the adjusted fertilizer recommended rates and the amount of $\mathrm{N}$ fertilizer sales is 1.0 (between 1.35 to 0.82 ) 
indicating that fertilizer recommendations are generally well followed in the province.

Many different agricultural adaptation scenarios can be devised, either with increased or decreased production intensity as compared to the present level. For the purpose of our study, a "worst case" scenario was selected because none of the adaptation scenarios is verifiable. Based on consensus expert opinion of Agriculture and Agri-Food Canada at the Research and Policy Branch, it was assumed that agricultural production in PEI would intensify over the next 50 years. Hence, relative to the 2001 census provincial totals, the following sequential agricultural land use scenario was developed for the 2040-2069 period (De Jong et al., 2008):

- the area of alfalfa, improved pasture, tame hay and other grain cereals reduces by $40,30,30$ and $15 \%$, respectively (total "freed-up" area: 29794 ha);

- the berries and vegetable area increases by $100 \%$ (remaining "freed-up" area: 25179 ha);

- of the remaining "freed-up" area, 20, 40 and $40 \%$ is allocated to potatoes, grain corn and soybeans, respectively;

- buffer strips, a legislative requirement, reduce the increased total area of potatoes by $5 \%$, with this area going into the "other land" category;

- for SLCs 538001, 537002 and 537003, the total area of potatoes decreases by $6 \%$, because these SLCs contain fields with steep slopes, and the "freed-up" area is allocated equally to tame hay and spring wheat;

- as a consequence of the decrease in perennial forages, the number of cattle decreases by $10 \%$; and

- the number of poultry and pigs increases by $30 \%$.

To calculate RSN for this agricultural adaptation scenario, the 1996 crop yields and $\mathrm{N}$ fertilization recommendations of Ontario were used because crop heat units and effective growing degree-days for this year were reported to be similar than those reported for the 2040-2069 period in PEI (Bootsma et al., 2001). Thus, the agricultural adaptation scenario depends on land use, crop yield and $\mathrm{N}$ fertilization recommendation changes induced by climate change. As done by De Jong et al. (2008), the RSN model was then run with this scenario to obtain 23 projected RSN values one for each polygon. The $\mathrm{N}$ mass was applied on the SLC polygons because RSN values are estimated over these entire polygons. RSN units are provided in $\mathrm{kg}$ of $\mathrm{N}$ per hectare of farmland area but farmlands are not defined within the SLC polygon. To provide conservative scenarios, it was assumed that the total RSN was nitrified and leached to the aquifer within the year. Moreover, to be compatible with the FEFLOW model, the transformed mass of $\mathrm{N}$ applied at the surface of the model was estimated by multiplying the RSN values by the ratio of farmland area over SLC polygon area. This operation maintains the total mass of nitrate over the SLC polygon but reduces the applied rate.

\subsection{Numerical groundwater flow and nitrate transport model}

The physically based FEFLOW model used to simulate groundwater flow and nitrate transport was divided into eight layers (four layers for each of the two flow systems). The base of the model is deep at $800 \mathrm{~m}$ below water table to include the different flow patterns that can develop within the PEI aquifer system (e.g., Tóth, 1963). The flow in the vadose zone was neglected due to the short lag-time response (few days) between precipitations and water table fluctuations. Boundary conditions include constant heads around the Island in the first layer, and no flow boundaries in the underlying layers to simulate the flow along the saline front around the Island. Constant heads were also applied to rivers on the first layer to represent the hydraulic connection between rivers and the high-flow system. Note that non-pumping conditions were considered for the calibration and future scenarios, as most of the Island is supplied by individual domestic wells sparsely spread over the Island (approximately 145000 inhabitants in 2014 , over $5660 \mathrm{~km}^{2}$ ). The impact of pumping wells on the water table is thus expected to be low ( $<2 \mathrm{~mm} \mathrm{yr}^{-1}$ based on a daily individual consumption of $200 \mathrm{~L}$ ), except in few localized areas where potable water is supplied by production wells (e.g., Charlottetown). Irrigation water for agriculture and associated return flow were not considered either because rainfall generally supplies the needed water demand for crops irrigation. The resulting three-dimensional grid contains 4896246 six-node prismatic triangular elements with an average element area of $0.0925 \mathrm{~km}^{2}$ (with triangle edges of approximately $430 \mathrm{~m}$ ).

The calibration of the FEFLOW model, which is an important step to narrow uncertainty in historical and future groundwater $\left[\mathrm{NO}_{3}\right]$, was carried out sequentially with three independent data sets: (1) hydraulic heads measured in domestic wells, (2) baseflow-recession curves for the main rivers, and (3) groundwater $\left[\mathrm{NO}_{3}\right]$ recorded in domestic wells.

\subsubsection{Hydraulic heads calibration}

The calibration of the FEFLOW model was first carried out under steady-state conditions with hydraulic head values measured at the time of drilling in more than 700 wells. These wells are domestic water wells, of varying depth, which generally end in the shallow high-flow system. Hydraulic heads were used to adjust the horizontal and vertical hydraulic conductivities within the reported range of values (Table 5) while keeping calibrated groundwater recharge values from the HELP model unaltered. The mean annual groundwater recharge for the 1971-2001 period was used. 
Table 5. Field-based and calibrated hydraulic properties of the FEFLOW numerical model for the Prince Edward Island aquifer system.

\begin{tabular}{llllll}
\hline Model & Field $K_{\mathrm{h}}$ & \multicolumn{4}{c}{ Numerical model } \\
\cline { 3 - 6 } $\begin{array}{l}\text { layer } \\
(\text { depth in m) }\end{array}$ & & $\begin{array}{c}K_{\mathrm{h}} \\
\left(\mathrm{m} \mathrm{s}^{-1}\right)\end{array}$ & $\begin{array}{l}K_{\mathrm{V}} / K_{\mathrm{h}} \\
(-)\end{array}$ & $\begin{array}{l}S_{\mathrm{y}} \\
(\%)\end{array}$ & $\begin{array}{c}n \\
(\%)\end{array}$ \\
\hline $1(0-5)$ & $4.5 \times 10^{-4}$ to $8.1 \times 10^{-5}$ & $3 \times 10^{-4}$ & 0.1 & 1 & 17 \\
$2(5-10)$ & & $1 \times 10^{-4}$ & 0.1 & 1 & 17 \\
$3(10-15)$ & & $5 \times 10^{-5}$ & 0.1 & 1 & 17 \\
$4(15-30)$ & $1.7 \times 10^{-4}$ to $8.4 \times 10^{-7}$ & $1 \times 10^{-5}$ & 0.01 & 1 & 17 \\
$5(30-80)$ & & $1 \times 10^{-5}$ & 0.001 & 0.1 & 17 \\
$6(80-180)$ & n.d. & $1 \times 10^{-6}$ & 0.01 & 0.1 & 17 \\
$7(180-380)$ & n.d. & $1 \times 10^{-7}$ & 0.1 & 0.1 & 17 \\
$8(380-880)$ & n.d. & $1 \times 10^{-8}$ & 1 & 0.01 & 17 \\
\hline
\end{tabular}

$K_{\mathrm{h}}$ and $K_{\mathrm{V}}$ : horizontal and vertical hydraulic conductivity, respectively; $S_{\mathrm{y}}$ : specific yield; $n$ : total porosity.

Using a time-averaged recharge value per model cell to represent present-day groundwater recharge conditions is justified by the facts that (1) no significant changing trend is observed in water table elevation at available long-term monitoring well hydrographs over the Island (Rivard et al., 2009), and (2) measured head data were collected over a considerable period of time ( $>40$ years). A comparison of the observed and predicted hydraulic heads indicates a similar trend with a relatively high correlation coefficient of $88 \%$, but show a fair amount of scatter and simulated heads slightly underestimated (Table 4). This is consistent with the fact that the observed head data were measured over several decades and likely reflect transient intra- and inter-annual head variations, which results in large uncertainty in mean head values, which is what the numerical groundwater flow model represents.

\subsubsection{Baseflow-recession calibration}

Once an acceptable match was obtained under steady-state conditions, the resulting model was used to simulate transient baseflow under recession conditions for the main rivers (Morell, Wilmot, Winter) to estimate specific yield (Table 5). With this procedure, groundwater recharge for the model is set to zero and daily discharge through the river nodes are compared to specific baseflow-recession events extracted from streamflow records. Baseflow-recession events for PEI occur generally at the end of summer during long periods of time without rainfall, when rivers are solely sustained by groundwater. The rate of decline of baseflow-recession curves is sensitive to a specific yield value, which controls the amount of water that can drain from the aquifer to the connected rivers (Mendoza et al., 2003; Sánchez-Murillo et al., 2015). A lower specific yield value is thus associated with a faster drainage of the aquifer. This dynamic is linked with groundwater and nitrate residence times that have a direct impact on the capabilities of the numerical model to predict meaningful groundwater $\left[\mathrm{NO}_{3}\right]$. The modeling of baseflowrecession events shows the best adjustment for a specific yield value of $1 \%$ (Table 4 ), which is attributed to the fractures in the sandstone aquifer. Note that recession curves are mostly sensitive to the high-flow layers, and specific yield values for underlying layers were progressively lowered to represent the decreasing number of fractures with depth (Table 5).

\subsubsection{Nitrate concentrations calibration}

After calibration of the groundwater recharge with HELP and the aquifer system dynamics with FEFLOW through head and baseflow-recession data, the historical mass of $\mathrm{N}$ leaching to the aquifer was adjusted to match present-day (20002005) $\left[\mathrm{NO}_{3}\right]$ measured in more than 17000 domestic wells. In PEI, intensive agriculture began around 1965 with the introduction of chemical fertilizers and has steadily increased since that time. The model of Paradis et al. $(2006,2007)$ for the Wilmot River watershed has illustrated the considerable time lag between increased leaching of nitrate and the buildup of groundwater $\left[\mathrm{NO}_{3}\right]$ corresponding to this increased input. This lag time is due to both the large capability of the PEI aquifer system to accumulate nitrate because of the large porosity of the sandstone, and the typically long residence time of groundwater from its recharge to its outflow in rivers. The maximum residence time of the high-flow and the shallow low-flow systems before discharge to the Wilmot River watershed was up to 20 and 10000 years, respectively. It can be assumed that a similar situation exists over the entire PEI aquifer system and that groundwater $\left[\mathrm{NO}_{3}\right]$ is presently not in steady-state equilibrium with the nitrate leachate that has historically prevailed in watersheds throughout PEI. Consequently, the numerical model needs to be run under transient conditions with the historical record of the mass of nitrate reaching the aquifer to ensure realistic predictions of groundwater $\left[\mathrm{NO}_{3}\right]$. Because $\mathrm{RSN}$ values were only estimated based on the 5 census years $(1981,1986,1991,1996,2001)$, no RSN estimate is available prior to 1981. Thus, for the onset of intensive agriculture in PEI from 1965 to 1981, an average 
Table 6. Temperature and precipitation changes for the future period (2040-2069) relative to the historical period (1971-2000) for each selected climate change scenarios at the Charlottetown weather station, Prince Edward Island (Qian and De Jong, 2007).

\begin{tabular}{|c|c|c|c|c|c|c|c|c|}
\hline \multirow[t]{4}{*}{ Scenario } & \multicolumn{4}{|c|}{ Temperature change } & \multicolumn{4}{|c|}{ Precipitation change } \\
\hline & \multirow{2}{*}{\multicolumn{2}{|c|}{$\begin{array}{c}\text { Monthly } \\
\text { mean } \\
\text { maximum }\end{array}$}} & \multirow{2}{*}{\multicolumn{2}{|c|}{$\begin{array}{c}\text { Monthly } \\
\text { mean } \\
\text { minimum }\end{array}$}} & \multicolumn{2}{|c|}{$\begin{array}{c}\text { Monthly } \\
\text { total } \\
(\%)\end{array}$} & \multicolumn{2}{|c|}{$\begin{array}{l}\text { Days with } \\
\text { Precipitation } \\
(\%)\end{array}$} \\
\hline & & & & & \multirow[t]{2}{*}{ Jan } & \multirow[t]{2}{*}{ Jul } & \multirow[t]{2}{*}{ Jan } & \multirow[t]{2}{*}{ July } \\
\hline & Jan & Jul & Jan & Jul & & & & \\
\hline CGCM2-A2 & 1.7 & 2.5 & 4.6 & 3.1 & -5.3 & 0.0 & -2.1 & 5.0 \\
\hline CGCM2-B2 & 1.1 & 1.8 & 4.0 & 2.2 & -8.1 & 5.0 & -3.8 & 1.8 \\
\hline HadCM3-A2 & 1.4 & 1.8 & 1.7 & 2.0 & 4.1 & 7.7 & -5.0 & -4.6 \\
\hline HadCM3-B2 & 1.2 & 1.4 & 1.5 & 1.5 & 5.1 & 1.4 & -3.0 & -1.9 \\
\hline
\end{tabular}

mass of nitrate representative for this period was adjusted to match observed present-day $\left[\mathrm{NO}_{3}\right]$. The estimates of mass of nitrate leaching to the aquifer based on the last 5 census years were not modified during the calibration process and it was assumed that all available RSN is transferred to the aquifer within the year of application.

As previously demonstrated by Savard et al. (2007), no significant denitrification occurs in the PEI aquifer system, and then only advective-dispersive transport was considered. Groundwater flow and nitrate transport were then run under steady-state and transient conditions, respectively, using hydraulic parameters summarized in Table 5 . Total porosity needed for the transport simulations were based on average laboratory values (Francis, 1989), whereas the effective diffusion coefficient, and longitudinal and transverse dispersivities were $1 \times 10^{-9} \mathrm{~m}^{2} \mathrm{~s}^{-1}, 5$ and $0.5 \mathrm{~m}$, respectively, considering typical groundwater flow path lengths (Gelhar et al., 1992).

As reported in Table 4 , the average $\left[\mathrm{NO}_{3}\right]$ measured in wells generally agrees with the simulated concentration for the SLC polygons for which RSN values are available. Simulated concentration is the average $\left[\mathrm{NO}_{3}\right]$ for the first four layers representing the high-flow system within which most domestic wells are installed. However, the simulated concentration slightly underestimates measurements (approximately $0.5 \mathrm{mg} \mathrm{L}^{-1}$ lower), as expected from the procedure of nitrate mass application at the surface of the model previously discussed. Based on the RMS value, the error in groundwater $\left[\mathrm{NO}_{3}\right]$ predicted by the FEFLOW model is $30 \%$.

\section{Results of modeling}

On the basis of the previous calibration results, it is assumed that the FEFLOW model provides a good representation of groundwater flow conditions and nitrate transport in the PEI aquifer system as well as of present-day $\left[\mathrm{NO}_{3}\right]$ in drinking water. For the purposes of this study, and knowing the uncertainty about groundwater recharge, hydraulic conductiv- ity, specific yield, porosity and nitrate mass, consideration will thus be given to the relative changes of future scenarios with respect to the calibrated FEFLOW model.

\subsection{Future climate scenarios}

The generated future climate scenarios show considerable warming from both GCMs (Table 6), although CGCM2 projected much greater warming than HadCM3 for the Charlottetown weather station (Fig. 1). Also, minimum temperature increases more markedly than maximum temperature, and warming under scenario A2 is more noticeable than under $\mathrm{B} 2$, as expected from higher $\mathrm{CO}_{2}$ emissions. While warming is expected throughout the entire year (July and January) for all scenarios, changes in precipitation appear uncertain, with total monthly precipitation and number of days with precipitation increasing or decreasing according to a specific scenario or season. Indeed, CGCM2 projects a slight decrease in precipitation for January with the opposite for HadCM3, even though the number of days with precipitation decreases in January for all scenarios. However, the projected July precipitation for 2040-2069 shows an increase or no change relative to the 1971-2000 averages for all four scenarios.

Scenario CGCM2-A2 shows a decrease in precipitation intensity during July (summer), as the number of days with precipitation increases and total precipitation remains unchanged. This can thus have an impact on surface runoff because a decrease in precipitation intensity results in less excess water to runoff during rainfall events. The scenario HadCM3-A2 shows on the contrary an increase in precipitation intensity for July. For January (winter), the surface runoff dynamics is more complex as snowpack thawing and form of precipitation (snow vs. rain) should be taken into account as previously done with the HELP model. 
Table 7. Summary of mean annual temperature and hydrologic cycle components (precipitation, evapotranspiration, surface runoff and groundwater recharge) simulated with the HELP model for the historical period (1970-2001) and the four climate scenarios (2040-2069) in Prince Edward Island. Values provided in brackets are the change in $\mathrm{mm}$ or ${ }^{\circ} \mathrm{C}$ for the $2040-2069$ period compared to historical conditions (1970-2001).

\begin{tabular}{llllll}
\hline Scenario & $\begin{array}{l}\text { Temperature } \\
\left({ }^{\circ} \mathrm{C}\right)\end{array}$ & $\begin{array}{l}\text { Precipitation } \\
(\mathrm{mm})\end{array}$ & $\begin{array}{l}\text { Evapo- } \\
\text { transpiration } \\
(\mathrm{mm})\end{array}$ & $\begin{array}{l}\text { Runoff } \\
(\mathrm{mm})\end{array}$ & $\begin{array}{l}\text { Recharge } \\
(\mathrm{mm})\end{array}$ \\
\hline Historic & 5.3 & 1173 & 583 & 221 & 369 \\
CGCM2-A2 & $8.0(+3.31)$ & $1109(-64)$ & $618(+35)$ & $155(-66)$ & $336(-33)$ \\
CGCM2-B2 & $7.0(+2.3)$ & $1223(+50)$ & $620(+37)$ & $209(-12)$ & $394(+25)$ \\
HadCM3-A2 & $6.7(+1.4)$ & $1141(-32)$ & $616(+33)$ & $202(-19)$ & $323(-46)$ \\
HadCM3-B2 & $7.1(+1.8)$ & $1197(+24)$ & $615(+32)$ & $221(0)$ & $361(-8)$ \\
\hline
\end{tabular}

\subsection{Hydrologic cycle components and groundwater recharge}

Simulation results for the historic period (1970-2001) show that almost $50 \%(583 \mathrm{~mm})$ of the annual precipitation is returned to the atmosphere by evapotranspiration (Table 7). Another $19 \%(221 \mathrm{~mm})$ is flowing to the rivers by surface runoff, and $31 \%(369 \mathrm{~mm})$ infiltrates the soil down to the sandstone aquifer as groundwater recharge. Moreover, groundwater recharge over the Island varies from $0 \mathrm{~mm} \mathrm{yr}^{-1}$ in wetland areas, to $704 \mathrm{~mm} \mathrm{yr}^{-1}$ over coarse sand soil (Fig. 4). The standard-deviation for groundwater recharge values is $50 \mathrm{~mm} \mathrm{yr}^{-1}$, in accordance with the homogeneity observed at the Island scale for climate as well as for the soil and geology.

For the 2040-2069 period, evapotranspiration values increase for all climate scenarios, as expected from the increase in temperature for the same period (Table 7). However, the variation in evapotranspiration is less marked than the variation in temperature. For surface runoff, values are predicted to be unchanged or decreased, with large variations ranging from 0 to $66 \mathrm{~mm}$ (Table 7). Those variations between scenarios are mainly related to the total precipitation available, evapotranspiration, decrease in precipitation intensity and snowpack dynamics as previously discussed. Total precipitation and groundwater recharge variations between scenarios follow similar patterns with increased values for the A2 scenarios (CGCM2 and HadCM3) and decreased values for the B2 scenarios with respect to the historic period (Table 7). In general, a decrease in groundwater recharge is expected for the 2040-2069 period (between 2.1 to $12.4 \%$ ); only the CGCM2-B2 scenario leads to an increase in recharge of $6.7 \%$.

\subsection{Residual soil nitrogen}

The components of the $\mathrm{N}$ balance were averaged over the 23 SLC polygons in PEI (Table 8). The total amount of $\mathrm{N}$ input from fertilizer, manure, leguminous crops and atmospheric deposition is $102.3 \mathrm{~kg} \mathrm{~N} \mathrm{ha}^{-1} \mathrm{yr}^{-1}$. The outputs con-

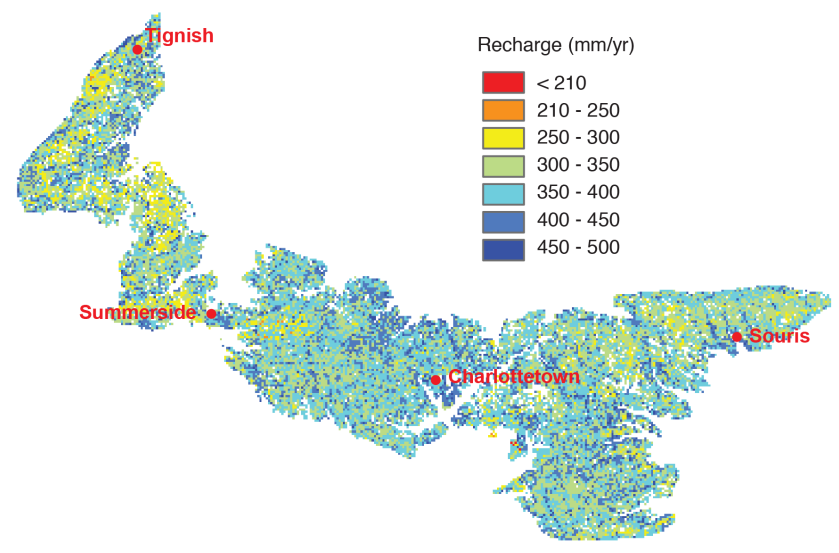

Figure 4. Spatial distribution of groundwater recharge from simulations with the calibrated HELP infiltration model for the historical period (1970-2001). Cell values are averages for the 1970-2001 period. Groundwater recharge is not shown for the 2040-2069 period as no significant changes were obtained from HELP based on climate change scenarios.

sist in $\mathrm{N}$ removed by cropping and gaseous losses, which total $71.5 \mathrm{~kg} \mathrm{Nha}^{-1} \mathrm{yr}^{-1}$. The province-wide average RSN is therefore $30.8 \mathrm{~kg} \mathrm{~N} \mathrm{ha}^{-1} \mathrm{yr}^{-1}$. The spatial variability of historical RSN values ranges from less than $25 \mathrm{~kg} \mathrm{~N} \mathrm{ha}^{-1} \mathrm{yr}^{-1}$ to approximately $40 \mathrm{~kg} \mathrm{Nha}^{-1} \mathrm{yr}^{-1}$ according to the local agricultural management practices (Fig. 5a).

With the agricultural adaptation scenario, $\mathrm{N}$ inputs from fertilizer were predicted to increase by $8.4 \mathrm{~kg} \mathrm{~N} \mathrm{ha}^{-1} \mathrm{yr}^{-1}$ relative to historical inputs (Table 8). The other inputs from manure, fixation and deposition remained relatively constant. $\mathrm{N}$ removal by crop uptake increases by $3.1 \mathrm{~kg} \mathrm{~N} \mathrm{ha}^{-1} \mathrm{yr}^{-1}$, and consequently residual soil $\mathrm{N}$ at the end of the growing season increases significantly from $30.8 \mathrm{~kg} \mathrm{Nha}^{-1} \mathrm{yr}^{-1}$ under historical management, to $35.7 \mathrm{~kg} \mathrm{~N} \mathrm{ha}^{-1} \mathrm{yr}^{-1}$ with the simulated adaptation scenario (16\% increase). The spatial variability of RSN under the adaptation scenario ranges from 28.3 to $46.1 \mathrm{~kg} \mathrm{Nha}^{-1} \mathrm{yr}^{-1}$ (Fig. 5b). The increase in RSN relative to historical data ranges from 10 to $23 \%$. 
Table 8. Average components of the nitrogen balance as simulated with historical crop and animal husbandry practices and with an adapted agricultural management scenario (De Jong et al., 2008).

\begin{tabular}{|c|c|c|c|c|c|c|c|}
\hline \multirow[t]{2}{*}{ Period } & \multicolumn{6}{|c|}{ Nitrogen inputs $\left(\mathrm{kg} \mathrm{Nha}^{-1} \mathrm{yr}^{-1}\right)$} & \multirow{2}{*}{$\begin{array}{c}\mathrm{RSN} \\
\left(\mathrm{kg} \mathrm{Nha}^{-1} \mathrm{yr}^{-1}\right.\end{array}$} \\
\hline & Fertilizer & Manure & Fixation & Deposition & Crop & Gas & \\
\hline Historical & 52.8 & 17.4 & 29.6 & 2.5 & 70.3 & 1.2 & 30.8 \\
\hline Adapted & 61.2 & 16.8 & 30.1 & 2.5 & 73.2 & 1.6 & 35.7 \\
\hline
\end{tabular}

RSN: residual soil nitrogen.

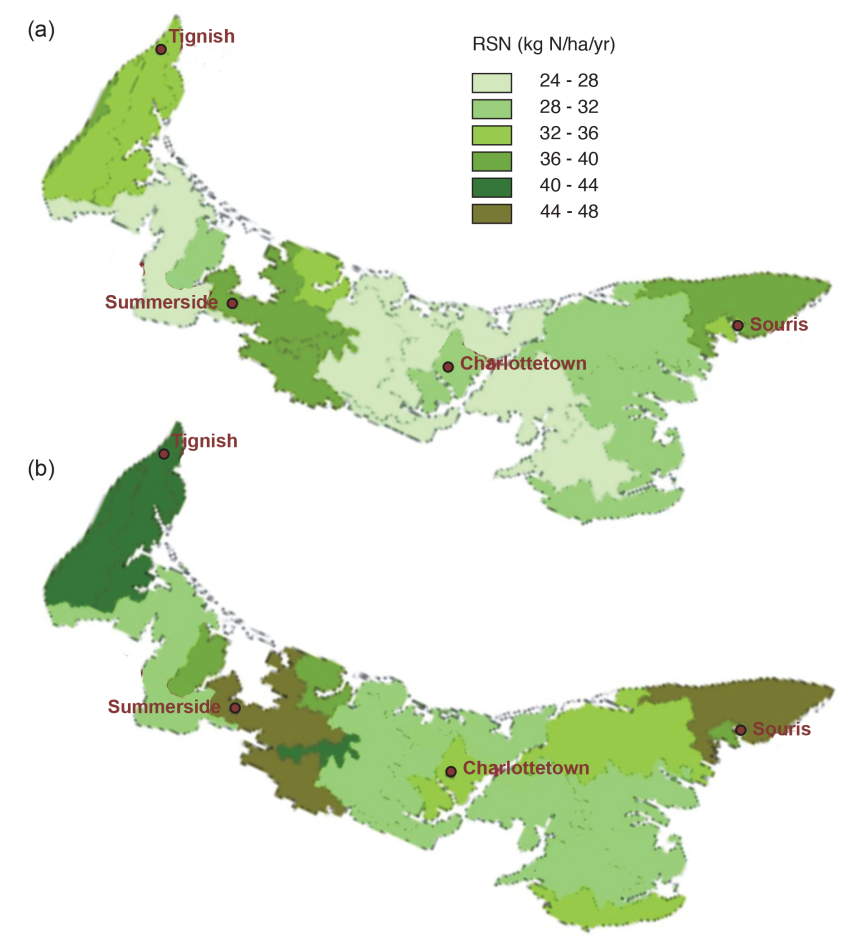

Figure 5. Simulated residual soil nitrogen (RSN) using (a) historical management practices and (b) the adaptation scenario presented in Table 8 (De Jong et al., 2008). RSN values are for each Soil Landscape of Canada (SLC) polygon.

\subsection{Nitrate concentration evolution simulations}

To assess the potential impact of climate change and agriculture adaptation in the future, nine groundwater flow and mass transport simulation scenarios were defined:

- Scenario 1 (Fig. 6b): this is the baseline scenario, which uses the mean historical groundwater recharge (steadystate flow) and the present-day agricultural practices (steady-state transport with RSN values from the 2001 census) from 2001 until 2069. This scenario is used to assess when aquifer concentrations are reaching steadystate conditions using present-day nitrate mass (equilibrium between nitrate inputs and outputs from the aquifer system).
- Scenarios 2 to 5 (Fig. 7a-d): these scenarios use the present-day agricultural practices (steady-state transport) in the SLC polygons but their groundwater recharge is based on the values obtained from the four climate scenarios (transient flow). The mass of nitrate applied over the watershed is kept constant for the 23 SLC polygons from 2001 until 2069. This mass represents the mean RSN value from the five past censuses (1981, 1986, 1991, 1996 and 2001). These scenarios combine the impact of aquifer system equilibrium and groundwater recharge change related climate changes on $\left[\mathrm{NO}_{3}\right]$.

- Scenarios 6 to 9 (Fig. 8a-d): these simulations use the RSN values modeled for the 2040-2069 period (transient transport) with the four climate scenarios along with the groundwater recharge based on the values obtained from these climate scenarios (transient flow). These scenarios combine the impact of $\left[\mathrm{NO}_{3}\right]$ equilibrium, groundwater recharge change and agricultural adaptation (land use and climate changes).

For the modeling purposes of this study, the gap between the last year of the calibration period (2001) and the beginning of the scenarios (2040) was then filled with gradual changes in groundwater recharge and RSN values to provide meaningful $\left[\mathrm{NO}_{3}\right]$ in the future. A linear interpolation between values established for 2001 and 2040 was thus applied.

Figure 6a presents map of the average $\left[\mathrm{NO}_{3}\right]$ per watershed for the present-day (2001) conditions obtained from the calibrated FEFLOW model. For comparison purposes, modeled groundwater $\left[\mathrm{NO}_{3}\right]$ were divided into four classes: background $\left(<1 \mathrm{mg} \mathrm{L}^{-1}\right)$, low $\left(1-3 \mathrm{mg} \mathrm{L}^{-1}\right)$, medium (3$5 \mathrm{mg} \mathrm{L}^{-1}$ ) and high $\left(>5 \mathrm{mg} \mathrm{L}^{-1}\right)$. These classes are used to emphasize that the model is more indicative of relative spatio-temporal changes in groundwater $\left[\mathrm{NO}_{3}\right]$ rather than absolute concentration values. This map shows that the most impacted watersheds are in the center of the Island where most agricultural activities are taking place. Histograms of the number of watersheds in each class reveal that $42 \%$ of the watersheds are in the medium (17) or high (4) $\left[\mathrm{NO}_{3}\right]$ classes (Fig. 6a; Table S1 in the Supplement). This observation reflects the critical situation that PEI is in regarding groundwater quality related to nitrate contamination. 

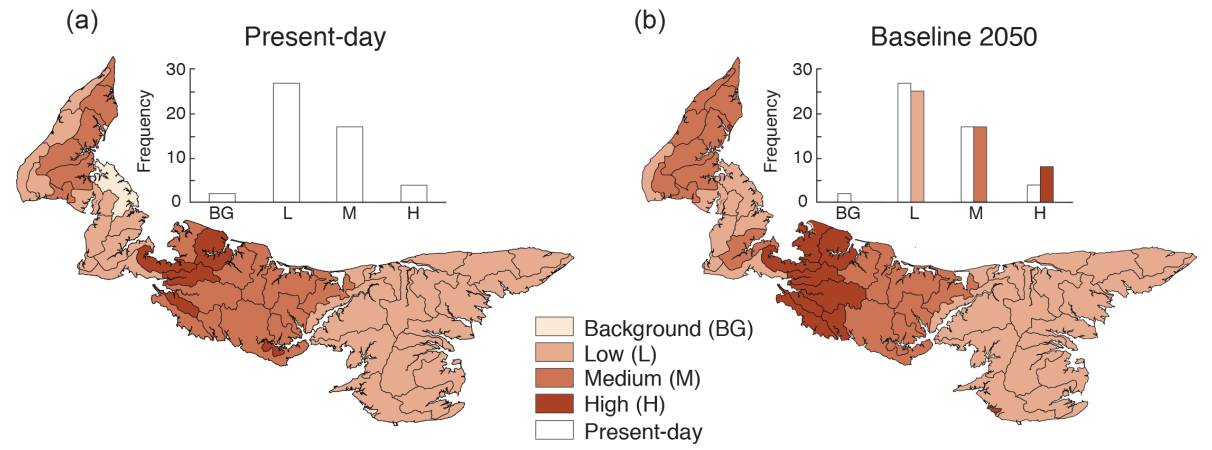

Figure 6. Class distribution of simulated mean nitrate concentration per watershed and histogram of the number of watersheds in each class for: (a) present-day (2001); (b) 2050 baseline scenario with present-day (2001) nitrate loading and groundwater recharge.

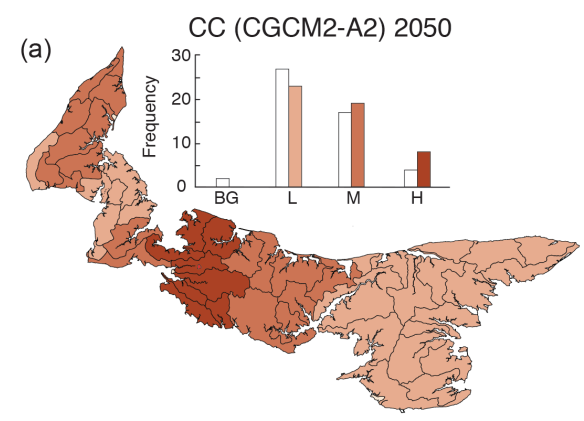

(b)

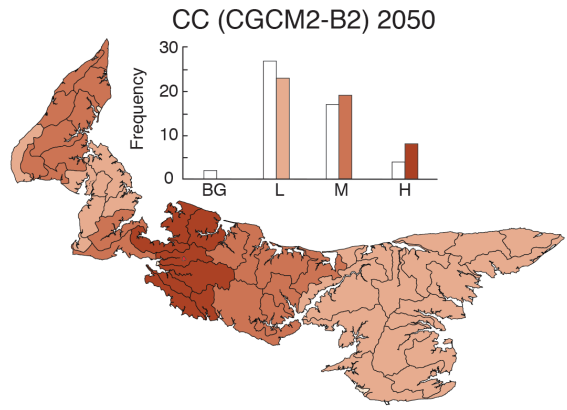

(c)

CC (HadCM3-A2) 2050

(d)

CC (HadCM3-B2) 2050

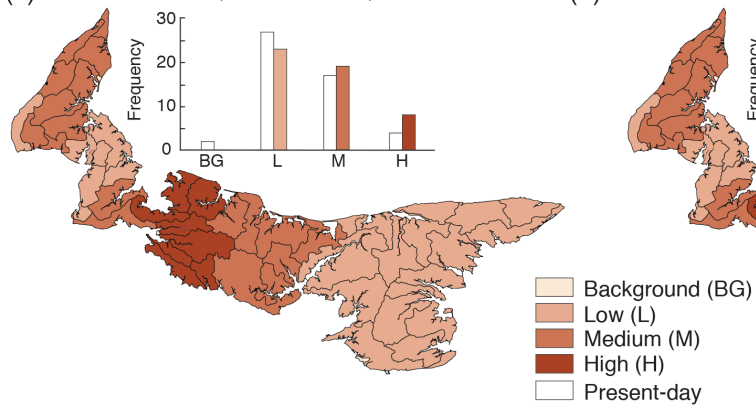

CC (HadCM3-B2) 2050

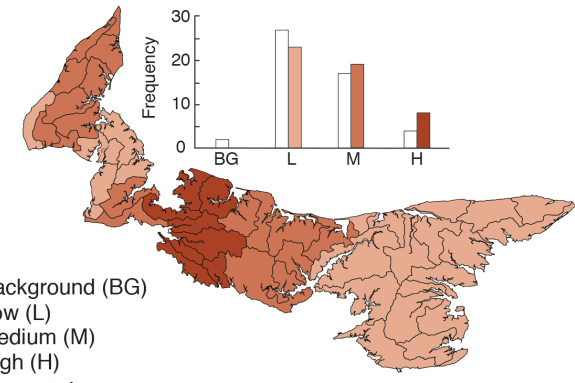

Figure 7. Class distribution of simulated mean nitrate concentration per watershed and histogram of the number of watersheds in each class for the four climate change (CC) scenarios $(\mathbf{a}, \mathbf{b}, \mathbf{c}$ and $\mathbf{d})$.

Note that for simplicity results are presented for 2050 (within the period 2014-2069). Compared to the present-day situation (Fig. 6a), the average increases in $\left[\mathrm{NO}_{3}\right]$ for the 2050 baseline scenario (scenario 1; Fig. 6b) is $11 \%$ for the Island (Table S1). This increase reflects steady-state in groundwater concentration due to gradual loading of nitrate using present-day concentration. Under the 2050 baseline scenario, the average nitrate content of several watersheds moves into a higher concentration class $-50 \%$ to the medium (17) and high (8) classes. The 2050 results show no more watershed at the background level (Fig. 6b; Table S1). Moreover, in the western part of the Island, several watersheds are predicted to reach the higher class, likely due to the longer residence times - i.e., a longer period before reaching equilibrium.
The average increase in groundwater $\left[\mathrm{NO}_{3}\right]$ over the Island for the four climate scenarios (2-5; Fig. 7a-d) ranges between 11 and $17 \%$ (Table S1) with respect to the presentday scenario (Fig. 6a). The departures from the baseline scenario suggest that the impact of groundwater recharge change alone (without the equilibrium effect) on $\left[\mathrm{NO}_{3}\right]$ is $6 \%$ for CGCM2-A2 and HadCM3-A2, $4 \%$ for HadCM3-B2, and zero for CGCM2-B2. There is thus also no significant change in $\left[\mathrm{NO}_{3}\right]$ classes and only two watersheds moving from the low to the medium class for all climate scenarios (Fig. 7a$\mathrm{d}$; Table S1). These simulations indicate that modification of the groundwater recharge regime caused by climate change (scenarios 2-5) has less impact on future water quality than reaching equilibrium with current nitrate mass (scenario 1 ). 

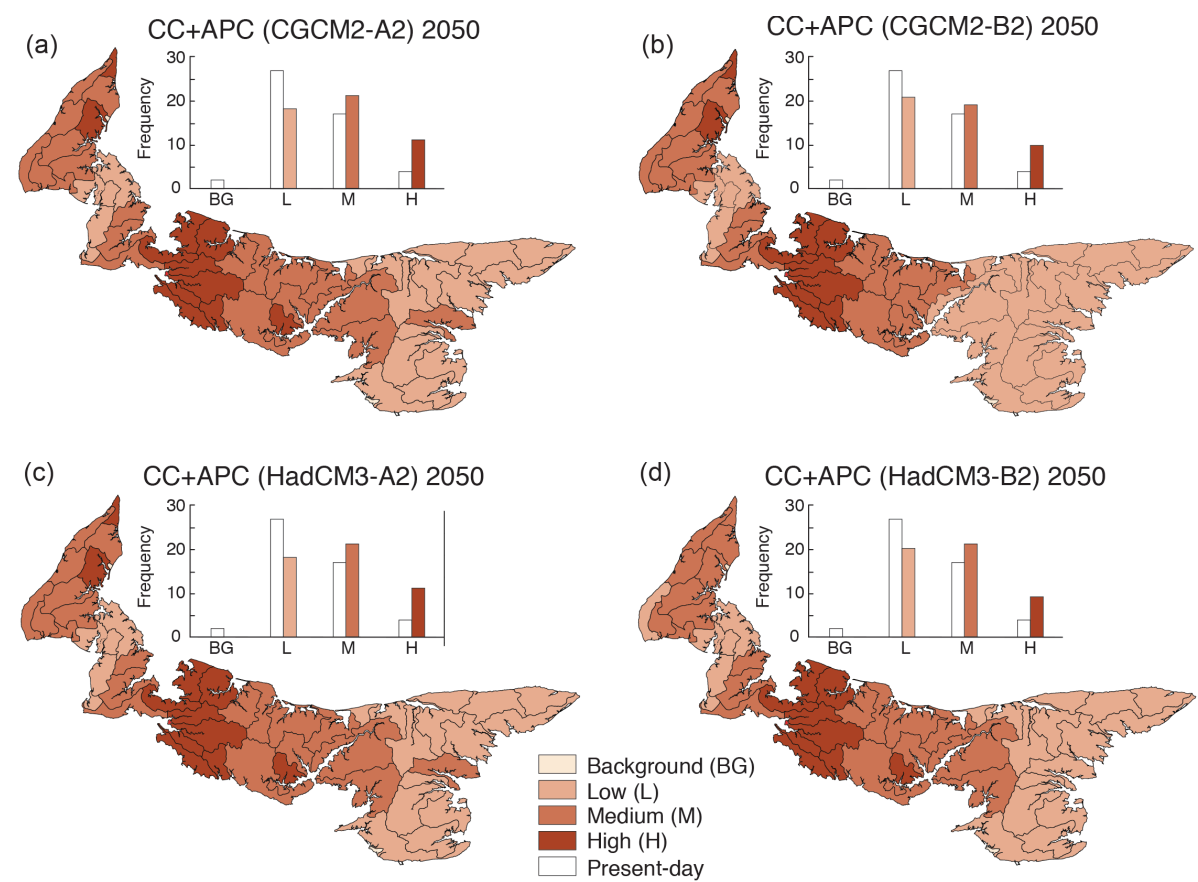

Figure 8. Class distribution of simulated mean nitrate concentration per watershed and histogram of the number of watersheds in each class for the four climate change (CC) scenarios with ensuing agricultural practice adaptation (APC) (a, b, c and d).

The Island average concentration for each climate scenario integrating the agricultural adaptation scenario ( 6 to 9 ; Fig. 8a-d) indicates a nitrate increase between 25 and $32 \%$ (Table S1) relative to the present-day simulation (Fig. 6a). The scenarios with CGCM2-A2 (scenario 6, Fig. 8a) and HadCM3-A2 (scenario 8, Fig. 8c) predict the highest impacts with $64 \%$ of the watersheds in the medium (17) or the high (8) class, while the scenario with CGCM2-B2 (scenario 7, Fig. 8b) has the lowest impact (58\% in medium or high class). The center of the Island is more strongly affected by high $\left[\mathrm{NO}_{3}\right]$, as expected from the intensification of agricultural activities for the 2049-2069 period (Fig. 5b). Moreover, the comparison of scenarios 6-9 with the baseline scenario indicates that changes in agricultural practices (land use and fertilization) and crop yields induced by climate change would have an impact on the increase of average $\left[\mathrm{NO}_{3}\right]$ of between 14 and $21 \%$ (Table S1). Thus agricultural adaptation will potentially have a greater effect on future groundwater $\left[\mathrm{NO}_{3}\right]$ in PEI than groundwater recharge change induced by climate change $(0-6 \%)$ or the reach of $\left[\mathrm{NO}_{3}\right]$ equilibrium in the aquifer system $(11 \%)$.

\section{Discussion}

\subsection{Comparison with previous studies}

De Jong et al. (2008) document the only other study on the assessment of the impact of climate and agricultural practice changes on groundwater quality for PEI. Similar to our study, they showed that the impact of the projected climate change on $\mathrm{N}$ leaching is small compared to the effect of agricultural intensification that could increase soil $\mathrm{N}$ leaching well above historical levels. While they showed that there was a reasonable qualitative agreement between simulated $\mathrm{N}$ leaching and groundwater $\left[\mathrm{NO}_{3}\right]$ in domestic wells, the sole simulation of $\mathrm{N}$ movement through the unsaturated zone does not allow a quantitative assessment of the effect of the aquifer system dynamics on $\left[\mathrm{NO}_{3}\right]$ in groundwater. Nevertheless, their simulations of $\mathrm{N}$ movement on a daily basis during the nongrowing season indicated that a few percent of the RSN was not reaching groundwater each year. On average, for all SLC polygons, $91 \%$ of the RSN was indeed lost via soil leaching, with a range from 87 to $96 \%$ over the Island. In comparison, we assumed that $100 \%$ of the RSN was reaching the aquifer system each year. On the other hand, De Jong et al. (2008) neglected $\mathrm{N}$ leaching during the growing season, which is contradicted by the findings of Savard et al. (2010) and Ballard et al. (2009), which showed important input of nitrate in groundwater throughout the year, including during the growing season.

The results obtained for PEI can also be compared to those reported by Ducharne et al. (2007) for the Seine Basin (France). The main findings of this study are indeed similar to those obtained for PEI. First, the dynamics of the aquifer system of the Seine Basin leads to an important increase in future $\left[\mathrm{NO}_{3}\right]$. This increase is however at least twice the percentage obtained for PEI by 2050, which suggests that the residence time of nitrate in the PEI aquifer system is shorter 
and it could equilibrate faster to a change in nitrate mass. This could be explained by the different geology between the two aquifer systems. For the Seine Basin, the influence of climate on groundwater recharge also has a minor impact on the increases of future $\left[\mathrm{NO}_{3}\right]$, as indicated by small to moderate decreases in river low flows (baseflow), so the reason why climate change leads to higher $\left[\mathrm{NO}_{3}\right]$ in groundwater is the increased nitrate leaching from the soils. This increased leaching is mainly related to enhanced crop biomass and yield as well as soil $\mathrm{N}$ mineralization (this process was not considered in our study). In our study, the increased nitrate leaching results from larger agricultural land, increased fertilizer use and higher crop yield. Thus, future studies in PEI should include a comprehensive simulation of nitrate movement through the unsaturated zone with a consideration of soil $\mathrm{N}$ mineralization to be more representative of actual and future agricultural conditions.

\subsection{Assessing model uncertainty through calibration}

In this study, the proposed workflow includes numerous modeling steps, which involve many hypotheses and conceptual choices. While a sensitivity analysis could be made on each of the many model parameters to quantify and propagate the uncertainty on groundwater $\left[\mathrm{NO}_{3}\right]$ predictions, the strength of our approach is rather to capitalize on known conditions that are used in a comprehensive calibration approach that constrains the possible range of model parameters. As reflected in Fig. 9, $\left[\mathrm{NO}_{3}\right]$ in groundwater depends on the mass of nitrate combined with the amount of water reaching the water table and the mixing of that infiltration with the flowing groundwater. Obviously, different combinations of nitrate mass, recharge and water flux could lead to the same $\left[\mathrm{NO}_{3}\right]$, and at least two of the three parameters need to be independently calibrated to obtain meaningful predictions of $\left[\mathrm{NO}_{3}\right]$ in groundwater. For this study, the flux of water coming from the surface (groundwater recharge) and flowing within the aquifer system were carefully calibrated with river baseflow and groundwater hydraulic head data. However, the mass of nitrate applied at the soil surface through RSN estimates was more uncertain at the scale investigated, and measurements in wells were instead used to calibrate $\left[\mathrm{NO}_{3}\right]$ in groundwater. Thus, the estimated mass of nitrate and flux of water (recharge and within the aquifer system) are likely representative of the actual conditions in PEI, and the performance of the FEFLOW model to predict $\left[\mathrm{NO}_{3}\right]$ in groundwater could be used to quantify the uncertainty propagated during the modeling process.

\subsection{Assessing uncertainty in future predictions}

Uncertainties in the projections related to climate models and forcing scenarios could be large, although the objectives of this study were to develop methodologies for assessing climate change impacts on groundwater $\left[\mathrm{NO}_{3}\right]$ and demonstrate

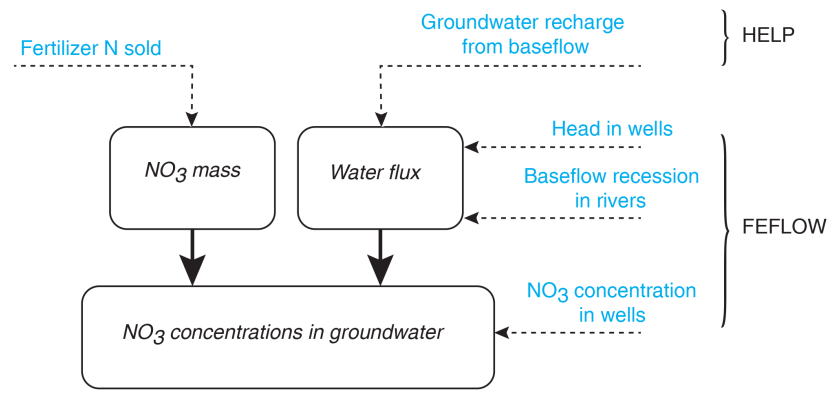

Figure 9. Schematic of the constraints exerted by conditions considered (in blue) in the calibration of model parameters for the simulation of processes controlling groundwater nitrate concentration $\left(\mathrm{NO}_{3}\right.$ mass leached and water fluxes, including recharge and groundwater flow).

their application in PEI. Projected climate changes by the two state-of-the-art GCMs, CanESM2 (Arora et al., 2011) and HadGEM2 (Johns et al., 2006; Martin et al., 2006), from the same climate modeling centers as CGCM2 and HadCM3, are presented in Table S2 under the Representative Concentration Pathways (RCP) 4.5 and 8.5. The projected temperature changes are larger in these new simulations. It is also noticed that an increase in July precipitation by over $20 \%$ was projected with little change or a decrease in the number of rainy days. Such changes could indicate increased precipitation intensity.

As reported by De Jong et al. (2008), N leaching in PEI is however considerably less sensitive to increases in daily precipitation than to decreases. For instance, a $15 \%$ increase in annual precipitation resulted in a $2.5 \%$ increase in $\mathrm{N}$ leaching, which is likely due to the high level of soil water saturation throughout much of the year in this temperate-humid climate. Thus, increased precipitation intensity could not result in a significant increase in $\mathrm{N}$ leaching to the aquifer system because much of the excess water will drain as surface runoff. Nevertheless, the projected groundwater $\left[\mathrm{NO}_{3}\right]$ under these new climate scenarios might differ from those based on CGCM2 and HadCM3 and uncertainties in the projections should be taken into account when results are used to develop adaptation strategies and policies.

Finally, while we considered only a single "worst case" agricultural adaptation scenario, it should be understood that this scenario was designed to explore the upper limits of potential future conditions. Thus, any adaptation strategy (e.g., better agricultural practices) will have to make sure that such an upper limit it not actually reached. This study thus serves as an indicator of the magnitude of the reduction needed on $\mathrm{N}$ leaching by agricultural adaptation strategies to counteract the projected increase in $\left[\mathrm{NO}_{3}\right]$ in groundwater. 


\section{Summary}

To assess the potential impact of climate change and the foreseen agricultural adaptation on $\left[\mathrm{NO}_{3}\right]$ in groundwater over the PEI, nine different groundwater flow and mass transport scenarios were considered. Simulations of these scenarios and their results expected for 2050 show that:

- the progressive change of groundwater $\left[\mathrm{NO}_{3}\right]$ simply due to reaching steady-state conditions related to present-day loading would generate an $11 \%$ increase of concentrations;

- groundwater recharge change related to climate change would only account for an increase of $0-6 \%$, whereas agricultural adaptations that include land use, fertilization, and crop yield changes induced by climate change would generate an increase of 14 to $21 \%$;

- the combined effect of equilibration with loadings, groundwater recharge change and agricultural adaptations would create an increase in $\left[\mathrm{NO}_{3}\right]$ between 25 and $32 \%$ over the PEI aquifer system.

As a consequence, the predicted general trend from 2001 to 2050 is that a significant number of watersheds would belong to the highly impacted group of watersheds having a mean $\left[\mathrm{NO}_{3}\right]$ exceeding $5 \mathrm{mg} \mathrm{L}^{-1}\left(\mathrm{~N}-\mathrm{NO}_{3}\right)$ with a recommended

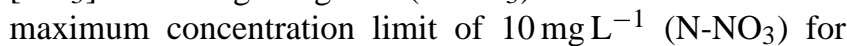
drinking water. In 2001, four watersheds of a total of 50 were in this group compared to the eight predicted for 2050 after reaching steady-state conditions and having undergone some of the climate change, or 9-11 after agricultural adaptation is also considered.

Finally, predicting the impact of climate change on groundwater quality in agricultural contexts represents a complex challenge that we have attempted to address using the case study of PEI. In that particular example, the main finding in support to decision making for sustainable development is that predicted climatic conditions combined with agricultural practices adapted to these conditions may be expected to generate significant degradation of water quality that would require modifying water servicing infrastructures, and develop better agricultural management practices to reduce nitrate leaching to the aquifer system (e.g., Zebarth et al., 2015; Somers and Savard, 2015). At a broader scale, we also have made progress in pinpointing key steps to be considered in predictive modeling, particularly in highlighting the need to produce sound and realistic scenarios of regionspecific agricultural adaptation to climate change while considering the specificity of the hydrogeological processes taking place, and applying a comprehensive calibration process to narrow the uncertainty in model parameters and results.

\section{The Supplement related to this article is available online at doi:10.5194/esd-7-183-2016-supplement.}

Acknowledgements. This study was funded by Natural Resources Canada (Climate Change Impact and Adaptation), and the Geological Survey of Canada (Groundwater Program). The authors are grateful to A. Shepard and M. Vanclooster for their constructive reviews and to the Editor M. Crucifix. A NSERC Discovery Grant supported R. Lefebvre. This is an ESS contribution 20150425.

Edited by: M. Crucifix

\section{References}

Allen, D. M., Mackie, D. C., and Wei, M.: Groundwater and climate change: a sensitivity analysis for the Grand Forks aquifer, southern British Columbia, Canada, Hydrogeol. J., 12, 270-290, 2004.

Allen, D. M., Cannon, A. J., Toews, M. W., and Scibek, J.: Variability in simulated recharge using different GCMs, Water Resour Res., 46, W00F03, doi:10.1029/2009WR008932, 2010.

Arora, V. K., Scinocca, J. F., Boer, G. J., Christian, J. R., Denman, K. L., Flato, G. M., Kharin, V. V., Lee, W. G., and Merryfield, W. J.: Carbon emission limits required to satisfy future representative concentration pathways of greenhouse gases, Geophys. Res. Lett., 38, L05805, doi:10.1029/2010GL046270, 2011.

Ballard, J.-M., Paradis, D., Lefebvre, R., and Savard, M. M.: Numerical modeling of the dynamics of multisource nitrate generation and transfer, PEI, Paper 210, GeoHalifax '09, 62th Canadian Geotechnical Conference and 10th Joint CGS/IAH Conference, 20-24 September 2009, Halifax, Canada, 1507-1514, 2009.

Beigi, E. and Tsai, F. T.-C.: Comparative study of climate-change scenarios on groundwater recharge, southwestern Mississippi and southeastern Louisiana, USA, Hydrogeol. J., 23, 789-806, 2015.

Bootsma, A., Gameda, S., and McKenney, D. W.: Adaptation of agricultural production to climate change in Atlantic Canada, Final report for Climate Change Action Fund Project A214, p. 30, 2001.

Burton, D. L. and Beauchamp, E. G.: Nitrogen losses from swine housings, Agric. Waste, 15, 59-74, 1986.

Canadian Soil Information System: National Soil Database, Agriculture and Agri-Food Canada, Ottawa, 2000.

CanImage: Landsat-7 Ortho-Images of Canada, 1/50000, Prince Edward Island, 2001.

Crosbie, R. S., McCallum, J. L., Walker, G. R., and Chiew, F. H. S.: Modelling climate-change impacts on groundwater recharge in the Murray-Darling Basin, Australia, Hydrogeol. J., 18, 16391656, 2010.

Croteau, A., Nastev, M., and Lefebvre, R.: Groundwater recharge assessment in the Chateauguay River watershed, Can. Water Resour, J., 35, 451-468, 2010.

De Jong, R., Qian, B., and Yang, J. Y.: Modelling nitrogen leaching in Prince Edward Island under Climate change scenarios, Can. J. Soil Sci., 88, 61-78, 2008.

Diersch, H.-J. G.: FEFLOW: Finite Element Subsurface Flow and Transport Simulation System-Reference Manual, v. 6.0, WASY GmbH Software, Berlin, p. 277, 2010.

Drury, C. F., Yang, J. Y., De Jong, R., Yang, X. M., Huffman, E., Kirkwood, V., and Reid, K.: Residual soil nitrogen indicator for Canada, Can. J. Soil Sci., 87, 166-177, 2007. 
Ducharne, A., Baubion, C., Beaudoin, N., Benoit, M., Billen, G., Brisson, N., Garnier, J., Kieken, H., Lebonvallet, S., Ledoux, E., Mary, B., Mignolet, C., Poux, X., Sauboua, E., Schott, C., Théry, S., and Viennot, P.: Long term prospective of the Seine River system: Confronting climatic and direct anthropogenic changes, Sci. Total Environ., 375, 292-311, 2007.

Flato, G. M. and Boer, G. J.: Warming Asymmetry in Climate Change Simulations, Geophys. Res. Let., 28, 195-198, 2001.

Francis, R. M.: Hydrogeology of the Winter River Basin, Prince Edward Island, Department of the Environment, Water Resources Branch, Prince Edward Island, p. 117, 1989.

Furey, P. R. and Gupta, V. K.: A physically based filter for separating base flow from streamflow time series, Water Resour. Res., 37, 2709-2722, 2001.

Gelhar, L. W., Welty, C., and Rehfeldt, K. R.:. A critical review of data on field-scale dispersion in aquifers, Water Resour. Res., 28, 1955-1974, 1992.

Ghiglieri, G., Barbieri, G., Vernier, A., Carletti, A., Demurtas, N., Pinna, R., and Pittalis, D.: Potential risks of nitrate pollution in aquifers from agricultural practices in the Nurra region, northwestern Sardinia, Italy, J. Hydrol., 379, 339-350, 2009.

Gleick, P. H.: Methods for evaluating the regional hydrologic impacts of global climatic changes, J. Hydrol., 88, 91-116, 1986.

Gordon, C., Cooper, C., Senior, C. A., Banks, H., Gregory, J. M., Johns, T. C., Mitchell, J. F. B., and Wood, R. A.: The simulation of SST, sea ice extents and ocean heat transports in a version of the Hadley Centre coupled model without flux adjustments, Clim. Dynam., 16, 147-168, 2000.

Green, T. R., Taniguchi, M., and Kooi, H.: Potential impacts of climate change and human activity on subsurface water resources, Vadose Zone J., 6, 531-532, 2007a.

Green, T. R., Bates, B. C., Charles, S. P., and Fleming, P. M.: Physically based simulation of potential effects of carbon dioxide altered climates on groundwater recharge, Vadose Zone J., 6, 597609, 2007b.

Hayhoe, H. N.: Improvements of stochastic weather data generators for diverse climates, Clim. Res., 14, 75-87, 2000.

Health Canada: Summary of guidelines for Canadian drinking water quality, Prepared by the Federal-Provincial-Territorial Committee on Drinking Water of the Federal-Provincial-Territorial Committee on Health and the Environment, http://www.hc-sc. gc.ca/waterquality (last access: 14 February 2016), 2004.

Hengeveld, H. G.: Projections for Canada's climate future: A discussion of recent simulations with the Canadian global climate model, Science Assessment and Integration Branch, Meteorological Service of Canada, Downsview, Ontario, Canada, p. 27, 2000.

Holman, I. P., Rounsevell, M. D. A., Shackley, S., Harrison, P. A., Nicholls, R. J., Berry, P. M., and Audsley, E.,: A regional, multisectoral and integrated assessment of the impacts of climate and socio-economic change in the UK: Part 1 Methodology, Climatic Change, 71, 9-41, 2005a.

Holman, I. P., Nicholls, R. J., Berry, P. M., Harrison, P. A., Audsley, E., Shackley, S., and Rounsevell, M. D. A.: A regional, multi-sectoral and integrated assessment of the impacts of climate and socio-economic change in the UK: Part 2 Results, Climatic Change, 71, 43-73, 2005b.

Holman, I. P., Tascone, D., and Hess, T. M.: A comparison of stochastic and deterministic downscaling methods for modelling potential groundwater recharge under climate change in East Anglia, UK: implications for groundwater resource management, Hydrogeol. J., 17, 1629-1641, 2009.

Hsu, K.-C., Wang, C.-H., Cheu, K.-C., Chen, C.-T., and Ma, K.W.: Climate-induced hydrological impacts on the groundwater system of the Pingtung Plain, Taiwan, Hydrogeol. J., 15, 903913, 2007.

Huffman, T., Ogston, R., Fisette, T., Daneshfar, B., Gasser, P. Y., White, L., Maloley, M., and Chenier, R.: Canadian agricultural land-use and land management data for Kyoto reporting, Can. J. Soil Sci., 86, 431-439, 2006.

IPCC - International Panel on Climate Change: Climate Change 2001, Working Group I: The Scientific Basis, http://www.grida.no/climate/ipcc_tar/wg1/index.htm (last access: 14 February 2016), 2001.

Jackson, B. M., Wheater, H. S., Wade, A. J., Butterfield, D., Mathias, S. A., Ireson, A. M., Butler, A. P., McIntyre, N. R., and Whitehead, P.G.: Catchment-scale modelling of flow and nutrient transport in the Chalk unsaturated zone, Ecol. Model., 209, 41-52, 2007.

Jackson, R. E., Mutch, J. P., and Priddle, M. W.: Persistence of aldicarb residues in the sandstone aquifer of Prince Edward Island, Canada, J. Contam. Hydrol., 6, 21-35, 1990.

Jiang, Y. and Somers, G.: Modeling effects of nitrate from nonpoint sources on groundwater quality in an agricultural watershed in Prince Edward Island, Canada, Hydrogeol. J., 17, 707724, 2009.

Johns, T. C., Durman, C. F., Banks, H. T., Roberts, M. J., McLaren, A. J., Ridley, J. K., Senior, C. A., Williams, K. D., Jones, A., Rickard, G. J., Cusack, S., Ingram, W. J., Crucifix, M., Sexton, D. M. H., Joshi, M. M., Dong, B. W., Spencer, H., Hill, R. S. R., Gregory, J. M., Keen, A. B., Pardaens, A. K., Lowe, J. A., BodasSalcedo, A., Stark, S., and Searl, Y.: The new Hadley Centre Climate Model (HadGEM1): Evaluation of coupled simulations, J. Climate, 19, 1327-1353, 2006.

Jyrkama, M. I. and Sykes, J. F.: The impact of climate change on spatially varying groundwater recharge in the grand river watershed (Ontario), J. Hydrol., 338, 237-250, 2007.

Jyrkama, M. I., Sykes, J. F., and Normani, S. D.: Recharge estimation for transient ground water modelling, Ground Water, 40, 638-648, 2002.

Martin, G. M., Ringer, M. A., Pope, V. D., Jones, A., Dearden, C., and Hinton, T. J., The physical properties of the atmosphere in the new Hadley Centre Global Environmental Model (HadGEM1). Part I: Model description and global climatology, J. Climate, 19, 1274-1301, 2006.

McCallum, J. L., Crosbie, R. S., Walker, G. R., and Dawes, W. R.: Impacts of climate change on groundwater in Australia: a sensitivity analysis of recharge, Hydrogeol. J., 18, 1625-1638, 2010.

McGinn, S. M. and Shepherd, A.: Impact of climate change scenarios on the agroclimate of the Canadian prairies, Can. J. Soil Sci., 83, 623-630, 2003.

Mendoza, G. F., Steenhuis, T. S., Walter, M. T., and Parlange, J. Y.: Estimating basin-wide hydraulic parameters of a semi-arid mountainous watershed by recession-flow analysis, J. Hydrol., 279, 57-69, doi:10.1016/S0022-1694(03)00174-4, 2003.

Monfet, J.: Évaluation du coefficient de ruissellement à l'aide de la méthode SCS modifiée, Service de l'hydrométrie, Ministère 
des Richesses Naturelles, Publication HP-51, Gouvernement du Québec, Québec, p. 35, 1979.

Mutch, J.: The hydrologic cycle and water movement, Nitrateagricultural sources and fate in the environment-perspectives and direction. Proceedings of the workshop, Eastern Canada Soil and Water Conservation Centre, Charlottetown, 3-7, 1998.

Nakicenovic, N. and Swart, R.: Special Report on Emissions Scenarios - A special report of Working Group III of the Intergovernmental Panel on Climate Change, Cambridge University Press, Cambridge, UK, p. 612, 2000.

Okkonen, J., Jyrkama, M., and Kløve, B.: A conceptual approach for assessing the impact of climate change on groundwater and related surface waters in cold regions (Finland), Hydrogeol. J., 18, 429-439, 2010.

Olesen, J. E. and Bindi, M.: Consequences of climate change for European agricultural productivity, land use and policy, Eur. J. Agron., 16, 239-262, 2002.

Ontario Ministry of Agriculture and Food: Soil fertility handbook, Publication 611, Ontario Ministry of Agriculture and Food, Ontario, 2003.

Paradis, D., Ballard, J.-M., Savard, M. M., Lefebvre, R., Jiang, Y., Somers, G., Shawna, L., and Rivard, C.: Impact of agricultural activities on nitrate in ground and surface water in the Wilmot Watershed, PEI, Canada, Paper 244, Proceedings, 59th Canadian Geotechnical Conference and 7th Joint CGS/IAH Conference, 1-4 October 2006, Vancouver, Canada, p. 8, 2006.

Paradis, D., Ballard, J.-M., and Lefebvre, R.: Watershed scale numerical modelling of nitrate fate and transport using spatially uniform averaged $\mathrm{N}$-inputs, in: Consequences of climatic changes on contamination of drinking water by nitrates on Prince Edward Island, Report of the Climate Change Action Fund: Impacts and Adaptation (A881/A843), edited by: Savard, M. M. and Somers, G., Natural Resources Canada, Quebec City, 49-62, 2007.

Prest, V. K.: Surficial deposits of Prince Edward Island, A-Series Map 1366A, Geological Survey of Canada, Ottawa, 1973.

Qian, B., Gameda, S., Hayhoe, H., De Jong, R., and Bootsma, A.: Comparison of LARS-WG and AAFC-WG stochastic weather generators for diverse Canadian climates, Clim. Res., 26, 175191, 2004.

Qian, B. and De Jong, R.: Modelling four Climate change scenarios for Prince Edward Island, in: Consequences of climatic changes on contamination of drinking water by nitrates on Prince Edward Island, Report of the Climate Change Action Fund: Impacts and Adaptation (A881/A843), edited by: Savard, M. M. and Somers, G., Natural Resources Canada, Quebec City, 63-71, 2007.

Qian, B., Gameda, S. B., De Jong, R., Falloon, P. D., and Gornall, J.: Comparing scenarios of Canadian daily climate extremes derived using a weather generator, Clim. Res., 41, 131-149, doi:10.3354/cr00845, 2010.

Qian, B., De Jong, R., Yang, J., Wang, H., and Gameda, S.: Comparing simulated crop yields with observed and synthetic weather data, Agr. Forest Meteorol., 151, 1781-1791, doi:10.1016/j.agrformet.2011.07.016, 2011.

Risser, D. W., Gburek, W. J., and Folmar, G. J.: Comparison of methods for estimating groundwater recharge and base flow at a small watershed underlain by fractured bedrock in the eastern United States, USGS Scientific Investigations Report 2005-5038, USGS, p. 31, 2005.
Rivard, C., Paradis, D., Paradis, S. J. , Bolduc, A., Morin, R. H., Liao, S. L, Pullan, S., Gauthier, M. J., Trépanier, S., Blackmore, A., Spooner, I., Deblonde, C., Fernandes, R., Castonguay, S., Michaud, Y., Drage, J., and Paniconi, C.: Canadian groundwater inventory: Regional hydrogeological characterization of the Annapolis-Cornwallis Valley aquifers, GSC Bulletin, 589, 86, 2008.

Rivard, C., Vigneault, H., Piggott, A. R., Larocque, M., and Anctil, F.: Groundwater recharge trends in Canada, Can. J. Earth Sci., 46, 841-854, 2009.

Rivard, C., Lefebvre, R., and Paradis, D.: Regional recharge estimation using multiple methods: an application in the Annapolis Valley, Nova Scotia (Canada), Environ. Earth Sci., 71, 1389-1408, 2014.

Rozell, D. J. and Wong, T.-F.: Effects of climate change on groundwater resources at Shelter Island, New York State, USA, Hydrogeol. J., 18, 1657-1665, 2010.

Sánchez-Murillo, R., Brooks, E. S., Elliot, W. J., Gazel, E., and Boll, J.: Baseflow recession analysis in the inland Pacific Northwest of the United States, Hydrogeol. J., 23, 287-303, doi:10.1007/s10040-014-1191-4, 2015.

Savard, M. M., Paradis, D., Somers, G., Liao, S., and van Bochove, E.: Winter nitrification contributes to excess $\mathrm{NO}_{3}^{-}$in groundwater of an agricultural region: A dual-isotope study, Water Resour. Res., 43, W06422, doi:10.1029/2006WR005469, 2007.

Savard, M. M., Somers, G., Smirnoff, A., Paradis, D., van Bochove, E., and Liao, S.: Nitrate isotopes unveil distinct seasonal $\mathrm{N}$-sources and the critical role of crop residues in groundwater contamination, J. Hydrol., 381, 134-141, 2010.

Schroeder, P. R., Aziz, N. M., Lloyd, C. M., and Zappi, P. A.: The hydrologic evaluation of landfill performance (HELP) model, Engineering documentation for version EPA/600/R-94/168b, Environmental Protection Agency Office of Research and Development, Washington, D.C., USA, p. 116, 1994.

Scibek, J. and Allen, D. M.: Modeled impacts of predicted climate change on recharge and groundwater levels, Water Resour. Res., 42, W11405, doi:10.1029/2005WR004742, 2006.

Serrat-Capdevila, A., Valdés, J. B., González Pérez, J., Baird, K., Mata, L. J., and Maddock III, T.: Modeling climate change impacts and uncertainty on the hydrology of a riparian system: the San Pedro Basin (Arizona/Sonora), J. Hydrol., 347, 48-66, 2007.

Soil Landscapes of Canada Working Group: Soil Landscapes of Canada v3.1, Agriculture and Agri-Food Canada (digital map and database at 1:1 million scale), Agriculture and Agri-Food Canada, Ottawa, 2006.

Somers, G.: Distribution and trends for occurrence of nitrate in PEI groundwater, in: Proc. from nitrate-agricultural sources and fate in the Environment-Perspectives and Direction, Grand Falls, Canada, 1998.

Somers, G. and Mutch, J.: Results of an investigation into the impact of irrigation wells on the availabilty of groundwater in the Baltic area, http://res.agr.ca/cansis/nsdb/slc/v3.1/intro.html (last access: 24 February 2016), 1999.

Somers, G. and Savard, M. M.: Shorter fries? An alternative policy to support a reduction of nitrogen contamination from agricultural crop production, J. Environ. Sci. Policy, 47, 177-185, 2015.

Somers, G. H., Raymond, B., and Uhlman, W.: Prince Edward Island water quality interpretative, Report 99 prepared for CanadaPrince Edward Island Water Annex to Federal/Provincial Frame- 
work Agreement for Environmental Cooperation in Atlantic Canada, p. 67, 1999.

Tóth, J.: A theoretical analysis of groundwater flow in small drainage basins, J. Geophys. Res., 68, 4795-4812, 1963.

USDA - United States Department of Agriculture: Urban hydrology for small watersheds, Soil Technical Release 55 (TR-55), Conservation Service, Engineering Division, Washington, D.C., USA, 1986.

Van de Poll, H. W.: Geology of Prince Edward Island, Prince Edward Island Department of Energy and Forestry, Energy Minerals Branch, Charlottetown, p. 66, 1983.

Viner, D.: The climate impacts LINK Project, Clim. Monit., 23, 3$5,1996$.

Woldeamlak, S. T., Batelaan, O., and De Smedt, F.: Effects of climate change on the groundwater system in the Grote-Nete catchment, Belgium, Hydrogeol. J., 15, 891-901, 2007.

Yang, J. Y., De Jong, R., Drury, C. F., Huffman, E. C., Kirkwood, V., and Yang, X. M.: Development of a Canadian agricultural nitrogen budget model (CANB v2.0): Simulation of the nitrogen indicators and integrated modelling for policy scenarios, Can. J. Soil Sci., 87, 153-165, 2007.
Young, J., Somers, G. H., and Raymond, G. B.: Distribution and trends for nitrate in PEI groundwater and surface waters, in: Proc. of National Conference on Agriculture Nutrients and their impact on Rural Water Quality, 29-30 April 2002, Agricultural Institute of Canada Foundation, Waterloo, Ontario, 313-319, 2002.

Yusoff, I., Hiscock, H. D., and Conway, D.: Simulation of the impacts of climate change on groundwater resources in eastern England, Sustainable Groundwater Development, Geol. Soc. Spec. Publ., 193, 325-344, 2002.

Zebarth, B. J., Danielescu, S., Nyiraneza, J., Ryan, M. C., Jiang, Y., Grimmett, M. G., and Burton, D. L.: Controls on nitrate loading and implications for BMPs under intensive potato production systems in Prince Edward Island, Canada, Ground Water Monit. R., 35, 30-42, doi:10.1111/gwmr.12088, 2015.

Zhou, Y., Zwahlen, F., Wang, Y., and Li, Y.: Impact of climate change on irrigation requirements in terms of groundwater resources, Hydrogeol. J., 18, 1571-1582, 2010. 